\title{
The Impact of Experiencing 5E Learning Cycle on Developing Science Teachers' Technological Pedagogical Content Knowledge (TPACK)
}

\author{
Mohamed Elfatih I. Mustafa \\ Faculty of Education, University of Ottawa, Canada
}

Copyright $(2016$ by authors, all rights reserved. Authors agree that this article remains permanently open access under the terms of the Creative Commons Attribution License 4.0 International License

\begin{abstract}
This study investigated the conditions and situations offered by Experiencing Inquiry Model (EIM) for developing science teacher's Technological Pedagogical Content Knowledge (TPACK). Also, the study explored the opportunities offered by EIM strategy in enhancing science teacher's abilities to design technology-based inquiry activities for science learning. Situated Cognitive Theory is used as a theoretical framework for learning, and TPACK is adapted to conceptualized technology integration. 17 science teachers from two schools participated in the study. The study employed a mixed method of quantitative and qualitative evidence. A paired sample t-Test was conducted on the participants' pre- and post-Pathfinder networks. Concurrently, the qualitative evidence was collected from researcher's logbook, participants' written documents, and interviews. The participants' abilities to design technology-based inquiry activity for science learning were examined via Technology Integration Assessment Rubric (TIAR). The analysis of the Pathfinder networks showed that there were significant developments in the participants' knowledge components embodied in TPACK. Nevertheless, the TIAR analysis suggested that the participants' designs lacked connecting curriculum goals with technology, and compatibility with curriculum goals and instruction. The study suggested that science teachers should be given amble time to develop TPACK within their instructional contexts.
\end{abstract}

Keywords Teacher Education, Science Education, 5E learning Cycle, TPACK

\section{Introduction}

\subsection{Background and Purpose of the Study}

Computer technology has been regarded as a tool to support many aspects of science instruction. National standards of science emphasize the promises of technology in engaging students in scientific inquiry, problem solving, and critical thinking activities [1,2].

Aligning with this vision, research studies suggest that science teachers should be offered opportunities to develop classroom instruction that takes advantage of the abilities of technology in enhancing science learning [3]. It is suggested that science teachers should develop decision-making abilities, reasoning skills, and critical thinking in relation to the integration of computer technology in classrooms [3-5]. More importantly, they need to develop an understanding of the pedagogical and content uses of technology. In their attempts to capture some of these notions, Mishra and Koehler[6] argue that "thoughtful pedagogical uses of technology require the development of a complex situated form of knowledge that we call Technological Pedagogical Content Knowledge (TPCK)" (p. 1017). McCrory[7] has added that understanding the pedagogical uses of technology includes: understanding of what role technology should play in teaching of science; where technology can be beneficial in science curriculum; in which learning context technology becomes important to use, and why; what technology features support specific learning expectations; and which technology is appropriate to simulate scientific concepts, and why. Unfortunately, this vision is not fully emphasized in educational technology training. So and Kim[5] argue that the inappropriate integration of technology in science classrooms is mainly due to the way educational technology training was proposed. Although the major goal of such training programs is to train science teachers how to use different technologies in classrooms, the training often does not focus on how to align technology with curriculum objectives, pedagogical goals, or science content $[3,8]$.

This study responses to the literature and investigates the effectiveness of Experiencing Inquiry Model (EIM) in developing science teacher's Technological Pedagogical Content Knowledge (TPACK). Also, the study explores the opportunities given for science teachers to negotiate their understanding of TPACK in designing technology-mediated 
inquiry-based learning activities. Prior to describing EIM, a brief description to the TPACK framework is given first.

\subsection{TPACK Framework}

TPACK was used as a framework to conceptualize the integration of computer technology in science instruction. This framework (Figure 1) consists of seven components: three primary components related to the understanding of technology (TK), pedagogy and teaching methodology (PK), and science content (CK). Also, the framework embodies domains that encompass the interrelationships between the primary components, which are Technological Content Knowledge (TCK), Pedagogical Content Knowledge (PCK), and Technological Pedagogical Knowledge (TPK)[6].

\subsection{Experiencing Inquiry Model (EIM)}

Windschitl[11] defines EIM as a strategy to explicitly guide teachers to experience inquiry as a model for teaching and learning of science. The main purpose of EIM is to provide opportunities for science teachers to conduct an inquiry before implementing it in the classrooms with their students. In EIM, teachers are given opportunities to recognize the inquiry processes, events, and structures [11]. While conducting the inquiry, teachers often strengthen their inquiry skills such as testing hypotheses, controlling and manipulating variables, revising and generating ideas or models, managing data collection, and analyzing data. Thus, this strategy provides teachers with direct guidance in understanding how students might learn a particular content area through inquiry. Moreover, EIM guides teachers through a sequence of learning tasks which can be used to help students conduct investigations, rather than leaving teachers to figure out how to support student learning through inquiry on their own. Besides experiencing the inquiry model, teachers can critically analyze the proposed inquiry tasks, and discuss the areas in which these tasks fail or succeed. The latter is a very important component of EIM because it advances teachers' understanding of how to design tasks that support student learning the most. Consequently, before teachers design their own tasks for science learning, they can use the same pedagogical framework in order to plan and develop a similar system of inquiry activities. In summary, the EIM strategy has shown successes in guiding teachers to develop their understanding of inquiry instruction as a model for teaching and learning of science $[11,26]$.

Nevertheless, EIM does not address the process through which teachers are able to develop technology-based inquiry activities. It also seems to pay insufficient attention to providing teachers with opportunities to explore and discover the uses of technology while conducting inquiry tasks. This missing component may help teachers recognize where their pedagogical or technological knowledge falls short [26]. This may allow teachers to work individually or collaboratively to develop wider domain of knowledge namely TPACK, as well as to negotiate their current knowledge structure in order to advance their instructional practices.

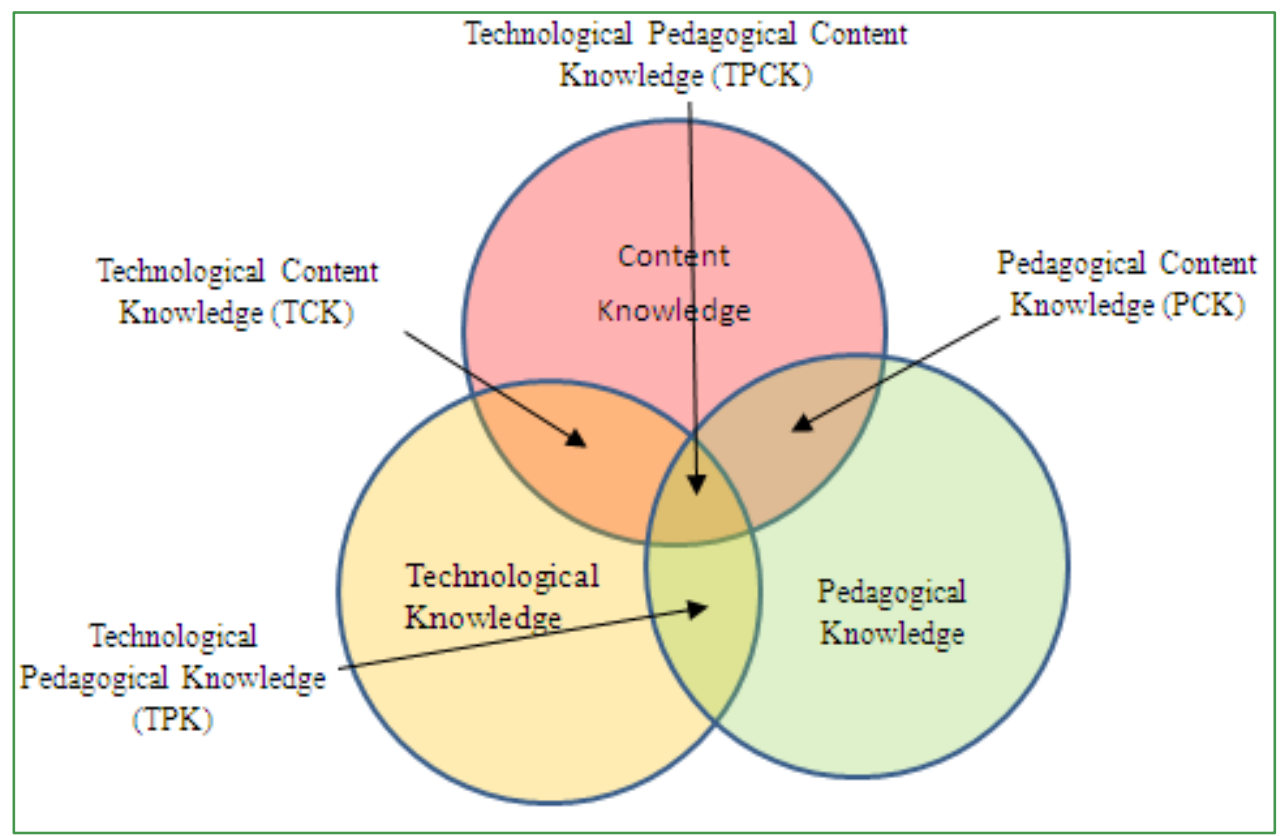

Figure 1. The components of the TPCK framework [6] 
In the context of this study, science teachers were presented to a scenario that simulated inquiry-based learning, and were exposed to conditions in which technology could be used to enhance teaching and learning of science. This condition aimed to help science teachers develop their TPACK in a context that simulated inquiry learning, and recognize the implications of their newly constructed TPACK in their planning choice of technology-based inquiry activities. Accordingly, the study aimed at investigating the impact of EIM on developing science teachers' TPACK, and examining their ability to incorporate this understanding in planning for technology-based inquiry activities. Thus, the following research questions were postulated:

1. What changes occur in science teachers' knowledge pertaining to the integration of computer technology (based on TPACK framework) as they learn through EIM?

2. What aspects of EIM are associated with these changes?

3. What aspects of the EIM strategy, or the participants' knowledge, afford opportunities to incorporate TPACK in designing technology-based inquiry activities?

The next section describes the context of the EIM strategy including the teaching and learning objectives, description of the target knowledge and concepts, and description of the guidelines for the EIM strategy.

\section{Context of EIM}

The main objective of the EIM strategy is to assist teachers in developing TPACK. As well, the proposed strategy is designed to help science teachers to negotiate their understanding of TPACK in order to inform their design of technology-based inquiry activities for science learning. This section describes the overall teaching and learning objectives; the context of learning, including descriptions of: science content, computer simulation used during the training, and pedagogical framework for inquiry approach; and the guidelines for the EIM strategy.

\subsection{Teaching and Learning Objectives}

The overall learning objective was to provide opportunities for science teachers to develop knowledge and skills deemed necessary to teach science with technology at the elementary and secondary divisions. During the learning process, science teachers were expected to deepen their understanding of specific science content, teaching through inquiry, and specific technology used to accomplish the inquiry tasks. Furthermore, science teachers were expected to recognize the interrelationships between science, pedagogy, and technology as pertaining to TPACK framework. Understanding of these relationships helps teachers to think strategically while engaged in planning, reflecting, and critiquing of specific learning situations. By the end of the study, teachers were expected to:

- experience the teaching and learning of specific science content via a guided-inquiry approach;

- identify pedagogical necessities as a rational for implementing computer technology in the classroom;

- critically evaluate the effectiveness of teaching science in a technology-rich guided inquiry environment;

- think critically and creatively in decision-making situations to inform the planning of technology-based learning activities for their students.

The teaching objectives were primarily designed to foster the learning objectives of the EIM strategy. Thus to support these objectives, and in the role of instructor, the researcher needed to:

- create environment in which teachers would engage in learning situations that simulate real classroom setting;

- implement 5E Learning Cycle (described in the next section) as a model for an inquiry approach;

- provide learners with the time, space, and resources needed for learning;

- implement various types of scaffolding techniques to guide learners to accomplish their learning tasks successfully; and

- utilize a range of assessment tools to evaluate the learning progress of the individuals and the class as a whole.

The teaching and learning objectives of EIM will be further described in the form of an action plan. However, prior to describing how the teaching and learning objectives were addressed, a brief description of the learning context will be given.

\subsection{Context of Learning}

The study aimed at providing opportunities for science teachers to develop the interrelationship between science content, inquiry, and computer technology while experiencing learning situations similar to ones that occur in science classrooms. During the learning process, teachers would be asked to utilize a Physics Educational Technology (PhET) computer simulation to complete an investigation into the construction of electric circuits in series and parallel. This section describes the three basic areas that teachers were expected to learn. Nevertheless, the main purpose of developing these areas is not to learn them in isolation, rather to understand the dynamic interrelationships between them in order to develop a technological pedagogical content knowledge. The three areas are related to: the construction of electric circuits $(\mathrm{CK})$, the $5 \mathrm{E}$ learning cycle (which is the general framework for inquiry learning - PK), and the PhET Circuit Construction Kit simulation (TK).

\subsubsection{Developing science content knowledge (CK)}

For the purpose of this study, science teachers from different grade levels were expected to conduct an 
investigation leading to the understanding of the construction and characteristics of series and parallel circuits. They would learn this content similar to the way Grade 6 students normally learn it in their schools. However, one may ask: Why the construction of electric circuits for Grade 6 in particular? Many reasons constitute the answer to this question. Initially, students in Grade 6 learn the fundamental concepts of static electricity and electric current. Teachers in this study came from different grade levels, and thus they were expected to gain first-hand experience in teaching and learning one of the fundamental concepts of science. By doing so, teachers would recognize the knowledge and skills necessary to understand the basic concepts of electricity. Consequently, they would be ready to prepare their students to construct a foundation for advanced topics in general science, physics, and chemistry courses at the secondary level. Moreover, elementary students often have alternative conceptions or misconceptions about electric potential energy, electric potential, and potential difference [27]. This would be an opportunity for teachers to learn how students' misconceptions could be addressed, and what kinds of teaching approaches could be used to address students' alternative conceptions.

In the process, science teachers were expected simulate students' roles in the classroom and understand the optimum conditions by which students could enhance their learning. One of the instructional models used to conceptualize the teaching and learning of science is the $5 \mathrm{E}$ learning cycle, which can also be used as a pedagogical framework to guide teachers through inquiry investigation.

\subsubsection{E Learning Cycle}

The basic idea of the $5 \mathrm{E}$ learning cycle is inspired by the Piagetian focus of construction of knowledge [28] and the Vygotskian notion of scaffolded learning [29]. It consists of five phases or events that provide learners with systematic guidance aimed at engaging their thinking in inquiry process such as testing hypotheses, collecting and analyzing data, and applying new knowledge in real-life situations. The five phases are: engage, explore, explain, elaborate, and evaluate. The purpose of the engage phase is to stimulate students' curiosity and get them involved in the investigation, while assessing their prior knowledge. During this phase, students first identify what they are expected to do, and then make connections between the current task and their prior knowledge and experiences. The explore phase aims to get students involved in the investigation, and provides them with the opportunity to build upon their initial understanding of the topic under investigation. In this phase, the students are guided through an inquiry process in which they postulate hypotheses, collect and organize data, and analyze data in order to come up with scientifically acceptable explanations in the explain phase. Thus, in explain phase, students are expected to negotiate what they have learned so far and try to come up with sound explanations for the results of their investigations. In the elaborate phase, students are given opportunity to apply their new knowledge to real-life situations. They are expected to expand on the concepts they have learned and make connections with previously learned concepts. Finally, the evaluate phase allows students and teachers to determine whether the learning outcomes of the inquiry have been achieved. It involves ongoing diagnostic and assessment processes used throughout the $5 \mathrm{E}$ phases.

For the purpose of this study, the $5 \mathrm{E}$ learning cycle was preferred as a general framework for developing teachers' pedagogical knowledge for a number of reasons. First, 5E consists of a distinctive sequence of events that starts with recalling the learner's prior knowledge (engage phase), leading up to applying new knowledge in different situations (elaborate phase). As well, the 5E learning cycle is commonly suggested by national standards (e.g., NRC, 2006). It has often been used in teaching and learning of science, mainly because $5 \mathrm{E}$ is well grounded in a foundation of contemporary research on student learning (NRC, 2006). Finally, experiencing the $5 \mathrm{E}$ learning cycle provides teachers with opportunities to recognize students' inquiry skills that are needed for investigations, understand the guidance needed to support students' learning, and more importantly, understand the challenges in the context of inquiry learning and teaching. The latter includes the ability to select appropriate computer technology (such as PhET simulations) as a rational to resolve inquiry challenges.

\subsubsection{PhET Circuit Construction Kit Simulation}

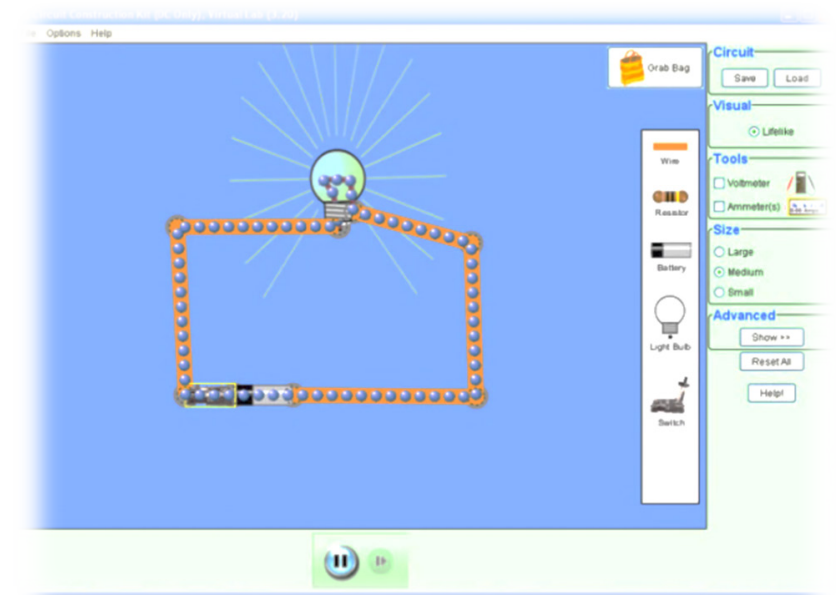

Figure 2. Main window of the PhET Circuit Construction Kit simulation (http://phet.colorado.edu/index.php)

The PhET Circuit Construction simulation was selected so that teachers could develop their technological knowledge. The simulation was selected from among the ones that are available on the PhET website [10]. This particular interactive simulation (Figure 2) allows manipulation of different variables such as resistance, current, potentials, number of batteries, and types of connecting wires. These features are intended to help users constructing simple circuits with minimum technical issues or hazards associated with the electrical wiring. Further, users could control 
variables to test the effect of other variables such as controlling the resistance of the circuit and test the relationship between current and potential (Ohm's Law). Consequently, the teachers could analyze the effectiveness of these features by assessing the possible advantages, disadvantages, or unrealistic simulations.

In summary, teachers would be given opportunities to develop three types of knowledge related to: a) the construction of a simple electric circuit $(\mathrm{CK}), \mathrm{b})$ the principles of the 5E learning cycle (PK), and c) the PhET computer simulation (TK). Nevertheless, the main purpose of developing technological, pedagogical, and content knowledge is not only to learn these domains in isolation, but also to understand the dynamic interrelationships between them. Therefore, teachers would be given further opportunities to discuss issues like:

- What were the features of the PhET simulation that would support students' learning of series and parallel circuits?

- What made the $5 \mathrm{E}$ learning cycle appropriate (or not) to achieve the target objectives?

- How could PhET and the 5E learning cycle work together to support students' understanding of electric circuits?

- What were the possible failures of the PhET simulation that might happen during the inquiry investigation, and how could these failures be avoided in the future?

The EIM strategy would be used to address such issues as well as to assist teachers to inform the planning of technology-based inquiry activities. The next section describes the guidelines of EIM.

\subsection{Guidelines for the EIM strategy}

For the purpose of this study, the EIM strategy consists of three parts (Figure 3): a) learning the 5E cycle, the PhET simulation, and electric circuits, b) utilizing the PhET simulation to conduct an inquiry via $5 \mathrm{E}$, and c) analyzing the design of the inquiry process. The following guidelines describe what teachers were expected to do during these three parts.

To prepare teachers for the training, the instructor would first introduce the PhET Circuit Construction Kit simulation, the $5 \mathrm{E}$ learning cycle, and the basic concepts involved in electric circuits. Learners would be expected to recognize the language comprehension or formal discourse that would be used during the training. For example, learners would recognize the meanings of: computer simulation, inquiry learning, student-centered approach, electric charges, current, potential difference, etc. Then, learners would complete hands-on activities to practice how to use the PhET Circuit Construction Kit simulation, discuss how to implement the parts of the 5E learning cycle, and clarify the general concepts of electricity.

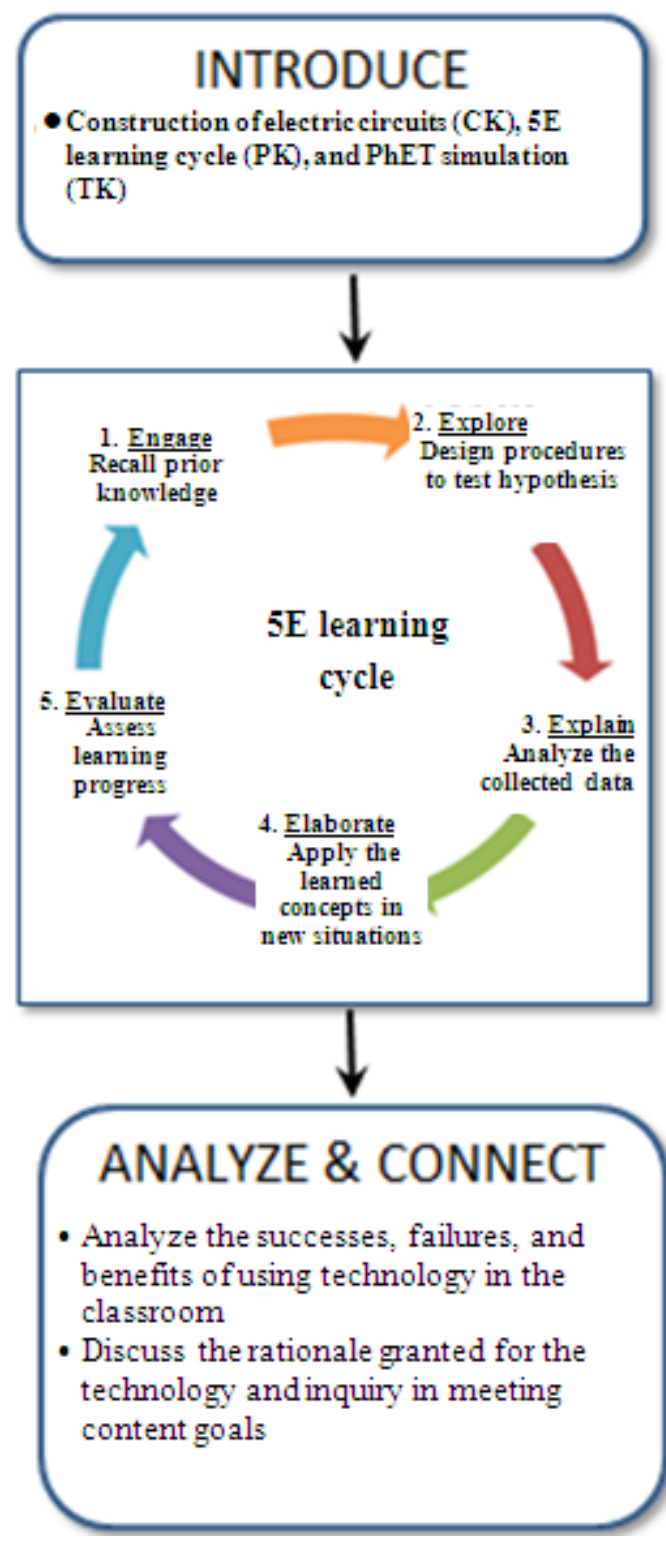

Figure 3. EIM strategy

Next, teachers would be asked to conduct an inquiry into the characteristics of electric currents in series and parallel circuits using the PhET Circuit Construction Kit simulation and the $5 \mathrm{E}$ learning cycle. Learners would progress through the 5E phases: engage, explore, explain, elaborate, and evaluate. In the engage phase, learners were expected to recall their prior knowledge and discuss how the brightness of two bulbs differs if they were connected in series and parallel circuits. Then, in the explore phase, learners would be asked to make a hypothesis or hypotheses about the situation posed in the first phase. The instructor would guide learners in designing an investigation to test their hypotheses using the PhET Circuit Construction Kit simulation. Data would be gathered and organized in the explore phase. In the explain phase, learners would be expected to analyze their data and come up with scientifically acceptable explanations for their findings. Learners could use the computer simulation at any time if they needed to confirm/disconfirm 
their explanations. Learners would then elaborate and apply their newly constructed knowledge in new situations. Besides guidance, the instructor would monitor and evaluate learning progress throughout the investigation.

Next, after conducting the inquiry investigation, learners would be expected to critically analyze the learning activities to develop a deeper understanding of the effectiveness of technology integration. In this stage, learners would be guided to critique the design of the learning activities, but the intention would not be to encourage them to reflect on their own learning. Learners would: a) critique the ways in which the PhET Circuit Construction Kit was beneficial (or not) for the teaching and learning of the construction of an electric circuit, b) establish whether the $5 \mathrm{E}$ tasks provided an adequate inquiry model to challenge students' alternative conceptions, and c) if not, what their drawbacks were. Such questions would be posed to encourage learners to think critically and establish a rationale for using the PhET simulation in their classrooms, the $5 \mathrm{E}$ learning cycle, and the target concepts. Such direction was expected to lead learners to develop a better understanding of the pedagogical and content uses of technology in the classroom as pertaining to the TPACK framework.

In conclusion, the EIM strategy would allow teachers to experience the 5E learning cycle in an environment similar to real classrooms. Learners would be provided with opportunities to analyze their precedent experience in order to develop an understanding of the interrelationships between the use of technology, pedagogy, and science content. The MS strategy, however, was developed to scaffold teachers' engagement in metacognitive learning.

\section{Research Method}

\subsection{Context of the Study and Participants}

The main objective of this study was to examine the impact of EIM strategy on developing science teacher's TPACK. Since TPACK is a framework that is often developed within a specific classroom context [12], it would be meaningless to measure the development of science teachers' TPACK without measuring their abilities to apply this knowledge in different contexts. Therefore, the study aimed to determine the impact of the EIM strategy in developing science teacher's abilities to incorporate their TPACK into the designing of technology-mediated inquiry-based activities. Considering the fact that the study intended to address the outcome of a treatment that is implemented in a dynamic, sensitive, and complex classroom setting, the study adopted a concurrent embedded strategy of mixed methods.

In this study, the quantitative data, as the primary source of data, was used to compare the development of the science teachers' TPACK. The qualitative data, as a secondary source of data, was used to examine the learning events experienced by the participants to determine what part(s) of the EIM strategy best afford this development. The qualitative data therefore helped to describe the context of the site where the quasi-experimentation took place, and the characteristics of the participants as they related to the design of the study and the anticipated outcomes. The qualitative data was also used to study the influence of various factors that could be at play within this context, which would be difficult to measure quantitatively.

Table 1. Participants' demographics

\begin{tabular}{ccccccc}
\multirow{2}{*}{ School } & \multicolumn{2}{c}{ Gender } & \multicolumn{2}{c}{ Teaching } & \multicolumn{3}{c}{ Grade Levels } \\
& $\mathrm{M}$ & $\mathrm{F}$ & Experience $(>5 \mathrm{yr})$. & $1-6$ & $7-8$ & $9-11$ \\
\hline A & 6 & 7 & 8 & 8 & 3 & 2 \\
B & 1 & 3 & 2 & 0 & 1 & 3 \\
Total & 7 & 10 & 10 & 8 & 4 & 5
\end{tabular}

17 science teachers participated in this study (10 females and seven males), and they came from two $\mathrm{K}-12$ private schools. Both schools teach all subjects, including sciences, in English. Since both schools included a wide range of grade levels (K to Grade 12), science teachers were usually asked to teach science at different levels, or asked to teach different subjects. Besides teaching sciences, a few participants were teaching other subjects such as ESL and math, and the others were teaching science at different grade levels. Despite of that, the context of this study was appropriate within the framework of professional development workshop because the main objective of the study was to guide science teachers to develop adequate understanding of the dynamic interplay between science content, teaching method, and technology regardless of the grade level. All the teachers completed bachelor degrees either in science, engineering, or science education. Table 1 shows some of the participants' demographic information such as gender, years of teaching experience, and grade level. 13 of the participants came from one school (School A) where they taught the national curriculum in English. The other four came from another school (School B) where they taught a home-made curriculum, in English, so their students (girls only) were prepared to take the International General Certificate for Education (IGCSE) - Cambridge Board Examination by the time they enter Grade 11. All participants spoke English as a second language, and spoke Arabic as a first language.

\subsection{Data Collection}

\subsubsection{Instruments}

Two sets of instruments were used for data collection procedures: quantitative instruments and qualitative instruments. The quantitative instruments were Pathfinder Network Scaling [13,14,15], Technology Integration Assessment Rubric (TIAR) [16], and demographic questionnaire.

Pathfinder Network Scaling is a computer-based network scaling technique that offers a quantitative method for representing and evaluating structural knowledge $[14,15]$. The pathfinder network is generated by an algorithm from proximities from pairs of entities or concepts. The network aims at representing the organization and conceptualization 
of knowledge involving understandings of facts, principles, and concepts, and most importantly, understanding how concepts of a particular knowledge domain are interrelated [17]. The proximities can be obtained from similarities, correlations, distances, conditional probabilities, or any other measure of the relationships among the concepts. In the pathfinder network, the concepts correspond to the nodes of the generated network, and the links in the network are determined by the patterns of proximities. More recently, knowledge networks are gaining more recognition as reliable tools for assessment and feedback instruction [18]. In the study, Pathfinder Network Scaling was used to assess the participants' knowledge structure pertaining to TPACK. To do that, initially, the participants rated the relatedness of different pairs of concepts pertaining to the TPACK framework. Appendix E illustrates the rating sheet and the concepts list that was generated from the integrated Technological Pedagogical Science Knowledge framework [19]. Then, the participants judged the relatedness of each pair of concepts on a numerical scale from completely unrelated (a rating of 1) to strongly related (a rating of 5). Pathfinder Network Scaling would then transform the relatedness data into network representations via the pathfinder network generation algorithms. Finally, the participants' networks were compared to a referent network to calculate the corresponding similarity index for each network. The referent network was created based on the average relatedness of three TPACK experts who had recently conducted and published research works related to science teachers' TPACK.

TIAR is outlined in Appendix C. It was used to evaluate teachers' ability to plan for technology integration [16]. TIAR is an instrument to assess the participants' planning of technology-based activities across three TPACK components - TPK, TCK, and PCK - as well as the "fit" of the selected content, teaching strategies, and technologies, considered together. TIAR consists of four assessment criteria: a) curriculum goals and technology, b) instructional strategies and technology, c) compatibility with instructional goals and instructional strategies, and d) fit (content, technology, and pedagogy together).

The participants completed a short questionnaire to describe their academic background and teaching experience. In this questionnaire, the participants were asked to briefly describe their gender, age, teaching experience, academic qualifications, and subject background. Also, the participants were asked about their background or experience related to: teaching science through inquiry, uses of ICT in the classroom, and concepts of construction of electric circuits.

The qualitative instrument included participants' written documents, the researcher's logbook, and focus group interviews. The written documents, such as the Learner's Guide, were used to assess the participants' learning progress, and analyze their efforts to plan for and reflect on their own learning. Also, participants' artifacts (such as discussion posters) were used to analyze their ability to connect what they learned during the workshop to their everyday teaching practice, behavior and performance, and level of engagement throughout the intervention. The logbook was used to maintain a record of activities and events occurring during the intervention. The logbook helped in creating descriptions of the learning process and analyzing the implementation of strategies as per the original guidelines, and provided more insight into the processes of teaching and learning throughout the study. The interview questions were prepared to gather information on how science teachers progress in their learning tasks throughout the intervention. Through interviews, it was also possible to understand the participants' perceptions of which part(s) of EIM influenced their understanding of TPACK, and the competencies necessary for technology integration in science instruction. Understanding of the latter concept is important in establishing the reason for incorporating TPACK components in activities planning. The participants' understanding of technology competencies would be cross checked with TIAR scores. All interview questions were semi structured with open ended questions (Appendix D).

\subsubsection{Data collection procedures}

Prior to data collection, the participants, from both schools, were grouped together and assigned to the EIM strategy. The strategy was implemented by the author and integrated within the general framework of professional development workshops. All the learning and teaching materials were prepared by the researcher. A research assistant was hired to assist in recording the actual implementation of the teaching and learning events, and managing the data collection procedures. The EIM workshop was conducted in the computer lab of one of the schools. The data were collected over two days, in August 2015. Each day lasted for three hours. The quantitative and qualitative data were collected simultaneously throughout the workshop. The procedures included six steps: a) introduction and fill up the demographic questionnaire, b) completing the pre-intervention pathfinder network, c) the learning activities (the intervention), d) completing the post-intervention pathfinder network, e) designing technology-based inquiry activity, and f) focus group interviews (Appendix A and Appendix B).

At the beginning of the workshop, the participants filled out the demographic questionnaire. Then, they were introduced to research objectives, procedures, and the basic principles of the assessment of knowledge structure via the Pathfinder Network Scaling [13]. In this step, the participants were introduced to nine concepts pertaining to three knowledge domains: a) Pedagogical Knowledge (PK), b) Technological Knowledge (TK), and c) Content Knowledge (CK). The nine concepts were generated from the integrated Technological Pedagogical Science Knowledge framework [19] (Appendix G). The participants were introduced to 5E learning cycle, PhET simulations, and electric circuits. Although the concepts of 5E learning cycle and electric circuits were introduced via direct instruction, the participants were engaged in hands-on activities to 
explore the general features and functions of the PhET simulation. The participants did not use the PhET simulation to learn the target content knowledge, rather they were asked to design simple electric circuits (consisted of a battery, connecting wires, switch, and bulb) to test the functions of each component in the circuit. But there were no attempts to construct series or parallel circuits (the target learning outcomes).

The participants were then asked to independently use Pathfinder Network Scaling to rate the relatedness of 36 pairs of concepts on a numerical scale from completely unrelated (a rating of 1) to strongly related (a rating of 5). The 36 pairs of concepts constitute all possible combinations of the nine concepts that were introduced in the first step. In the end, the participants' rating sheets were gathered to generate the pre-intervention similarity indices. Table 3 shows a sample of the Pathfinder Network Scaling rating sheet. To avoid random ratings, the participants were instructed to justify their related and strongly related ratings (i.e., ratings of 4 and 5 , respectively). If the participants could not justify their high ratings, the instructions were to select uncertain ratings such as maybe related (a rating of 2) or somehow related (a rating of 3 ) instead. Presented here are the descriptions of the data collected during the learning activities. The researcher used his logbook to describe the process of learning activities and all events that occurred, and to record the performance of the participants and their attitudes towards learning.

The learning activities were conducted in two days. In the first day, the participants conducted an inquiry into the properties and characteristics of series and parallel circuits. They used the PhET Circuit Construction Tool simulation and the 5E learning cycle to complete their investigation. Initially, the participants were asked to pair up and work in groups. Each group had two to three members. The instructor began with the first phase of $5 \mathrm{E}$, the engage phase, and introduced a short scenario about a man who wants to decorate his community center with lights, but is puzzled by the type of connection he should use - parallel or series circuits. The objective of the scenario was to recall the participants' content knowledge. The participants were asked to respond to questions related to the scenario. They discussed these questions and worked in groups to come up with consensus answers. Overall, the answers were mixed. Regardless, the participants needed to focus on the process of inquiry investigation, such as formulating hypotheses, collecting and analyzing data, and coming up with acceptable explanations. The participants were instructed to manage their time wisely. In the explore phase, they were instructed to design a hypothesis and then design an investigation to test their hypothesis. They were then asked to conduct the investigation and write down their observations and conclusions (whether their hypotheses were accepted or rejected). Due to the time constraint, the participants could not complete the explain and elaborate phases, though the instructor had gone over these two parts.

On the second day, the participants had one session left in their training, the third session: analyzing the 5E learning activities. The participants were asked to critically analyzing the design and the process of the 5E learning tasks. More specifically, the participants were asked to address the following issues:

- the effectiveness of the PhET simulation in achieving the learning objectives

- whether the selection of the PhET simulation and the $5 \mathrm{E}$ cycle fit together and in what way

- the rationale for choosing the 5E learning cycle as a pedagogical framework for inquiry learning

In order to develop such types of knowledge, different types of inquiry models were described. Based on the roles of teachers and students in the inquiry spectrum, the instructor described discovery learning, Predict-Observe-Explain (POE) [30], the 3-phase learning cycle, and the 5E learning cycle. The instructor drew a distinct line between these models in terms of teacher-student interaction and the degree to which students can take control of their own learning. Further, the instructor described different types of technology that are commonly used in science classrooms, such as computer simulations, hypermedia applications, multimedia devices, BBL or LMS, and Web-based learning.

At the beginning of the discussion period, the participants were organized into six groups (two to three members in each). Three issues were posted for discussion and each issue pertained to a TPACK component. Each group chose an issue for discussion, and they spent an average of 20 minutes addressing the issue. They were then asked to share their ideas and thoughts with the whole class via posters and short presentations. They used these posters to organize their main ideas and comments and then discuss them with the class. Each group was given 10 minutes to present their issue and 10 minutes to discuss it with the class. At the end of the third session, the participants took a short break before proceeding to the next step.

Then, the participants were asked to independently rate the relatedness of the same 36 pairs of concepts, which they had completed before the intervention, in order to assess their knowledge structure after the learning activities. This assessment aimed at indicating any changes in the participants' networks that may have occurred during the intervention. Similar to the pre-intervention pathfinder networks, the participants were instructed to justify their related and strongly related ratings (i.e., ratings of 4 and 5, respectively), and if they could not justify their high ratings, they were asked to select a rating of either 3 or 2 instead. In the end, the participants' ratings sheets were gathered to generate the post-intervention similarity indices.

Then the participants were asked to apply what they learned to inform the planning of technology-mediated inquiry-based activities for their own students. For this assignment, the participants were provided with a template (Appendix F) to help them focus on technology integration. They were asked to select the technology of their choice that 
would meet specific instructional and curriculum objectives. To complete the assignment, the participants were required to describe the target content of their choice, instructional strategy, technological tool, and a brief description of learning sequences. The latter aimed to reveal the participants' ability to fit science content, technology, and pedagogy together in a logical sequence of events. The participants' assignments were evaluated, by the research and two Ph.D. (Ed.) students, according to TIAR. The participants' plans were rated in the four criteria from strongly aligned (a rating of 4 ) to not aligned (a rating of 1 ).

Finally, focus group interviews were conducted at the end of the second day, when the all assignments and learning events had been completed. For each interview session, the participants were organized into 3-4 groups (each group consisted of 4-5 members). The interviews were conducted to understand the participants' learning experiences and opinions of their assigned tasks, and their views of their understanding of the dynamic interrelationship between pedagogy, technology, and content matter. The interviews explored the participants' opinions on how aspects of the implementation of the EIM strategies impacted their development of TPACK. As well, during the interviews, the participants were asked to bring some insights into their performances and on the part(s) of the strategies that influenced their learning the most, as well as their understanding of the competencies that are deemed necessary for technology integration. Appendix D contains the interviews questions.

\subsection{Data Analysis}

The mixed methods approach aimed at responding to the research questions and objectives. Whereas the qualitative data was used to describe the aspects of implementation of the EIM strategy, the quantitative data was used to examine the impact of EIM in developing science teachers' TPACK, as well as assessing science teachers' ability to inform their planning choice of technology integration for science instruction. Considering the EIM strategy as the independent variable, and the participants' Pathfinder networks (i.e., similarity indices) as the dependent variables, a paired sample $t$-test on the mean differences between the participants' pre- and post-similarity indices was conducted. The Statistical Package for the Social Sciences (SPSS, version 23) was used for data analysis. The analysis was computed at the 0.05 level for statistical significance. TIAR was used to assess the participants' ability to take into account the pedagogical and content uses of technology to inform the planning of technology-mediated inquiry-based activities. The qualitative data was analyzed simultaneously with the quantitative data. The participants' written documents and Researcher's logbook were coded and then analyzed to clearly describe the actual implementation process as well as the participants' attitude ion to the implementation of the strategy that couldn't be determined by the quantitative data. The transcripts of the interviews were freely coded [31] to look for words, concepts, or patters to generate themes related to the research questions.

\section{Results}

\subsection{Statistical Results}

Table 2 describes the mean and standard deviation of the participants' pre- and post-Pathfinder networks as indicated by the similarity indices. The descriptive statistics of the preand post-similarity indices showed that the participants improved their knowledge structure, as indicated by the increase in the average similarity index.

Table 2. Pre- and post-similarity indices

\begin{tabular}{ccc}
\hline & Pre- & Post- \\
\hline Mean & .291 & .38 \\
Standard Deviation & .126 & .098 \\
Standard Error Mean & .034 & .026 \\
$\mathrm{~N}^{*}$ & 14 & 14 \\
\hline${ }^{*} 3$ pac
\end{tabular}

*3 participants, out of 17 , failed to submit either a pre- or post-

Pathfinder Network.

The inferential statistics showed that there were significant statistical differences between the pre- and post-similarity indices $(t(13)=-2.944, p=.011)$. This means the participants' post-Pathfinder networks have become more coincident with the referent network. Since the referent network represented the averaged network of three TPACK experts, this result indicated significant development in the participants' TPACK. The descriptive statistics of the TIAR scores showed performed well in two assessment criterions: relating instructional strategies and technology, and the fit between technology pedagogy and content. Figure 4 describes the frequency distribution of the TAIR overall scores. The graph shows that $53 \%$ of the participants scored 6.0 points, while $40 \%$ scored between 8 and 12 points. The low TAIR scores are mainly due the lack of understanding of the compatibility with curriculum goals and instruction and relating curriculum goals with technology (Table 3).

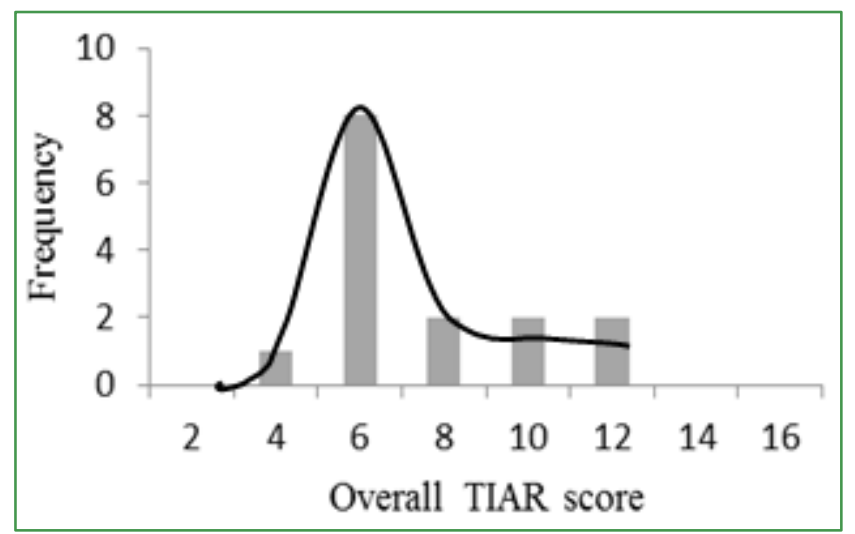

Figure 4. Distribution of the TIAR scores 
Table 3. Descriptive statistics of TIAR scores

\begin{tabular}{ccccc}
\hline Assessment Criteria & $\mathrm{N}^{*}$ & Mean & $\begin{array}{c}\text { Std. } \\
\text { Dev. }\end{array}$ & $\begin{array}{c}\text { Std. } \\
\text { Error } \\
\text { Mean }\end{array}$ \\
\hline $\begin{array}{c}\text { Curriculum Goals and } \\
\text { Technology }\end{array}$ & 15 & 1.720 & .580 & .1500 \\
$\begin{array}{c}\text { Instructional Strategies and } \\
\quad \text { Technology } \\
\begin{array}{c}\text { Compatibility with } \\
\text { Curriculum Goals and } \\
\quad \text { Instructional }\end{array}\end{array}$ & 15 & 1.913 & .889 & .2297 \\
$\begin{array}{c}\text { Fit technology pedagogy } \\
\text { and content together } \\
\text { TIAR total scores }\end{array}$ & 15 & 1.807 & .855 & .2209 \\
\hline
\end{tabular}

* 15 participants out of 17 completed their assignment.

\subsection{Qualitative Analysis}

The qualitative data was collected to understand the participants' learning processes and the conditions offered by EIM strategy to help the participants develop TPACK. In this study, EIM strategy was implemented in a learning environment that emphasized an educational context (i.e., the $5 \mathrm{E}$ learning activities) through which the participants could construct their knowledge individually or socially. To do that, they were explicitly guided to accomplish a sequence of activities bounded to educational context. Accordingly, it can be assumed that the development of the participants' knowledge occurred at three occasions, during: a) participants-instructor interaction, b) peer interaction, and c) interaction with the learning environment.

\subsubsection{Developing TPACK}

The quantitative data indicated that the participants learned through these three interactions without distinctive boarders between them. However, a large portion of this learning occurred during the $5 \mathrm{E}$ learning tasks and the discussion period. For example, the participants indicated that their interaction with the instructor was beneficial during the 5E learning activities as well as during group discussion. Further, they shed more light on the positive impact of experiencing $5 \mathrm{E}$ in developing their knowledge, and hence the development of their understanding of the relationship between technology, science content, and pedagogy.

During the 5E activities, the participants utilized the PhET simulation to complete the $5 \mathrm{E}$ tasks. They developed a rational of using the simulation to learn about the properties of series and parallel circuits. Despite the technical difficulties, the participants were able to use the PhET simulation to construct series and parallel connections, and find out what type of circuits would light all bulbs with maximum brightness, regardless of their number. The participants recognized the differences between the series and parallel circuits in different ways. Some groups hypothesized that lamps connected in series circuits would light brighter regardless of their number, and when they tested their hypothesis they found out it was rejected. This enterprise helped the participants in developing content knowledge related to the properties of series and parallel circuits as presented by the PhET computer simulation. Other groups pushed the PhET simulation to the extreme limit and discovered some of the simulation drawbacks. Some participants were concerned about some features and functions in the PhET simulation such as representation of the flow of electrons in the circuit. The simulation represents the electrons as spherical balls flowing from the negative terminal towards the positive terminal of the battery. The participants argued that this particular feature may send a misleading message or confusion about the scientific representations of particles at atomic scale. Whether it was a failure or success, the participants identified potential benefits and drawback of the PhET simulation. They analyzed the potential benefits and disadvantages of the simulation in order to identify the lessons learned. They realized that technology is not always perfect. Therefore teachers need to be very cautious before utilizing technologies in classroom. They should present technologies that best serve the curriculum objectives and best present scientific concepts as accurately as possible.

The qualitative evidence indicated that the participants developed better understanding of the interrelationships between technology pedagogy and content matter. Nevertheless, no evidence suggested that the participants developed a comprehensive understanding of TPACK as whole. When asked about the type of teacher's knowledge deemed necessary for technology integration, $50 \%$ of EIM participants said the technological knowledge (TK) is the most important knowledge. The other 50\% said TPK and TCK are important for effective integration of ICT. No one indicated that PCK or TPACK are important domains of knowledge for technology integration. Subsequently, the study concluded that EIM participants developed different aspects of knowledge embodied in TPACK, but no evidence to indicate that the participant developed TPACK as whole.

\subsubsection{Opportunities offered by EIM}

In the focus-group interviews, when the participants were asked "Which part of the EIM strategy helped you learn the most?" their reactions were quite consistent. They referred the " $5 \mathrm{E}$ activities as the part where they learned the most". More specifically, "the experiment explore phase....[was] a learning curve for me....". "This is a good method of teaching electric circuits." In this line many participants referred to the fact that the EIM strategy allowed them to learn in an environment that was very similar to classroom context. They conducted an investigation similar to that conducted with grade 6 students. They had an opportunity to think like students while progressing through the $5 \mathrm{E}$ learning tasks. Then, they analyzed, as teachers, their precedent learning events. For example, in the interview when asked about why the $5 \mathrm{E}$ activities were meaningful, a participant said, "I think $5 \mathrm{E}$ is effective for both, teachers and students....... For example, students aren't told anything about electric circuit. They made their observations, conduct their experiment, and [observe] the results of their 
experiment in real time."

In addition, the learning opportunities offered during the $5 \mathrm{E}$ activities were associated with effective guidance. The role of the instructor was acknowledged by the participants not only for enhancing their own learning, but also as a model for teaching through inquiry. In this line, a participant appreciated the roles of the instructor saying:

“...I really benefited from the role of teacher [instructor].......especially the role of teacher as a facilitator [during the 5E tasks] this is more beneficial for me to learn how to run $5 E$ tasks with my students....Also, I agree with my colleagues regarding the fact that conducting an experiment [during explore phase] is one of the most interesting part. Because in a normal science classroom we usually make demonstrations to natural phenomena and we ask our students to take notes or watch what we do...."

Other parts of the EIM strategy afforded opportunities to develop teachers' knowledge. A few participants referred to the third part of the training (i.e., analyzing the $5 \mathrm{E}$ learning activities). For example, one participant said:

"I think the most important part of the workshop is analyzing the $5 E$ tasks..... and relating so many things [with what] we have learned in the workshop"

Actually, the Researcher observed that the participants articulated different issues in order to comprehend their understanding of TPACK. For example, during group discussion the participants discussed whether the PhET simulation is appropriate for teaching their own students within the framework of 5E. One group talked about the effectiveness of the PhET simulation for teachers and students. For teachers they described the effectiveness of the simulation in facilitating the teaching sequence. For students, the simulation would support student-centered environment. The group elaborated on the latter point and argued that their students would be able to learning science more actively while designing and conducting investigations, collecting and analyzing data, and testing hypotheses. Another group discussed the impact of PhET simulation on developing students' operational skills. Consequently, at the end of the group discussion, the participants attempted to focus on the effectiveness of the PhET in implementing the 5E learning cycle, as well as in enhancing students understanding of electric circuits. The participants were able to spot the advantages and disadvantages of the PhET simulation.

In conclusion, qualitative data indicated that the vast majority of the participants (13 participants) acknowledged the opportunities offered by the $5 \mathrm{E}$ learning activities. The $5 \mathrm{E}$ learning activities offered first-hand experience not only to learn science content, but also to explore different guiding methods that were used (during the workshop) to facilitate the inquiry learning. Nevertheless, a few participants believed that the discussion period offered them opportunities to develop a global view of the ICT integration in a science classroom, including the potential advantages and disadvantages of technology that might support students' learning.

\section{Discussion and Implication}

The primarily objectives of this study were to examine the impact of the EIM strategy in developing science teachers TPACK to negotiate the planning choice for technologybased inquiry activities.

\subsection{Developing science teacher's TPACK}

What changes in science teacher's knowledge structure pertaining to the integration of computer technology occur as they learn through EIM?

The quantitative results of this study indicated that EIM afforded opportunities for the participants to develop TPACK knowledge as indicated by the paired sample t-test of the participants' Pathfinder networks. However, it is important to highlight that the statistical analysis of the Pathfinder network scaling was not inclusive in determining the TPACK components the participants could develop the most. The qualitative analysis, though, provided more insight in to the types of TPACK subdomains that had been developed during the intervention. The qualitative analysis suggested that the participants developed three TPACK subdomains (i.e., TCK, TPK, and PCK). The interview transcript and the content analysis of the participants' written documents indicated that these particular subdomains were developed across the subjects with various degrees. However, it can't be concluded to what level or depth these subdomains were developed. Also, the qualitative analysis did not show any indication that the participants did develop TPACK as a whole. These findings were further supported upon a closer look at the participants' Pathfinder networks.

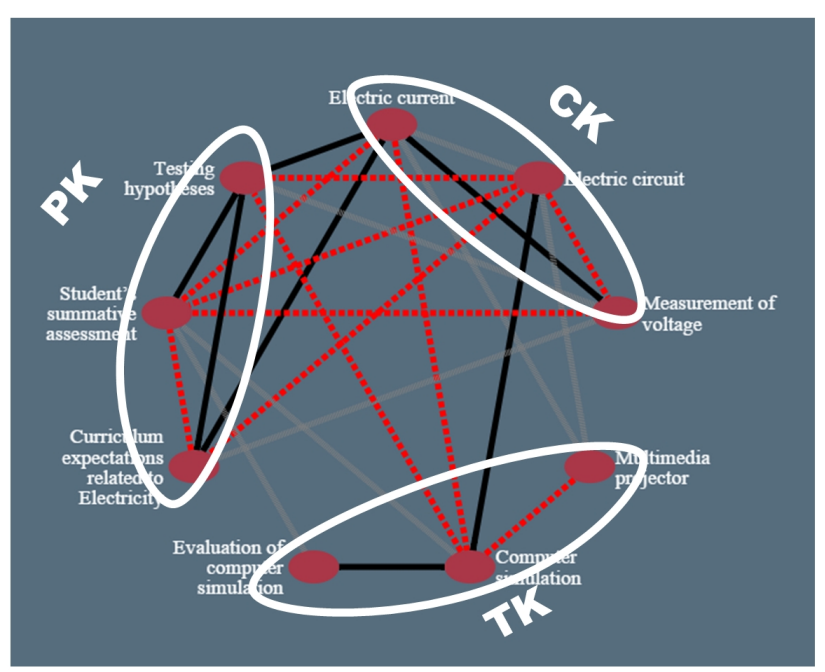

Figure 5. Pre-network of an EIM participant indicating the missing links (broken red lines)

The participants' Pathfinder networks showed that there was improvement in establishing direct links between 
various concepts related to 5E, PhET simulation, and construction of electricity. In fact, the participants' networks showed that there were specific direct links developed, and these links described the participants' understanding of TPK, TCK, and PCK. Nevertheless, the direct links that would entail the TPACK as a whole were still missing. This trend was observed consistently throughout the data set.

For example, Figure 5 shows the pre- network of an EIM participant. The pre-network shows the missing of direct links that describe the interrelationships between technology-pedagogy, technology-content matter, and pedagogy-content matter (as indicated in broken red lines). The post-network of the same participant (Figure 6) shows that these missing links are significantly reduced and replaced by direct links that describe the participant's TPK, TCK, and PCK only. However, the direct links that entail TPACK as whole (as viewed by the white triangle) are still incomplete. This result echoes with some researchers who have investigated the development of science teacher's TPACK and found out that TPACK cannot be developed in short-term training sessions, or without having this development flourished by meaningful experience in classrooms. Rather TPACK is often developed by teacher's accumulative experiences of technology integration and TPACK-specific training [20]. In this study, the participants spent 6 hours of training. It seemed they needed more time of training and instructional practice to develop more sophisticated level of TPACK. In order to do that, they should conceive TPACK as a dynamic body of knowledge and not static relationships between three domains (i.e., technology, pedagogy, and content matter). Therefore, understanding these dynamic interrelationships requires significant number of hours in classroom instruction associated with TPACK-specific training [6].

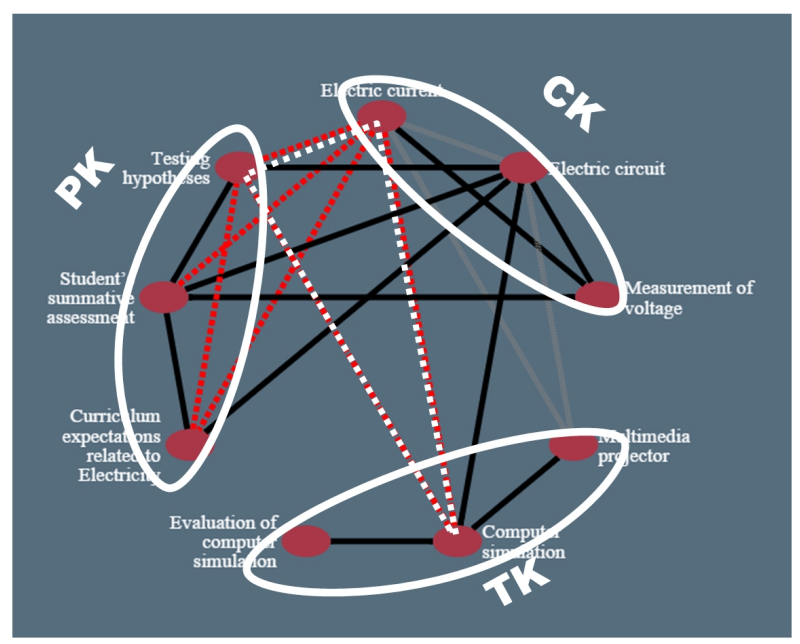

Figure 6. Post-network of an EIM participant indicating the missing links of TPACK

A number of TPACK researchers argue that TPACK should be developed within educational contexts that make sense to teachers $[12,23,7]$. Kelly[21] describes TPACK-context as one of the most important, complex, and least tangible components of the TPACK framework. This context consists of a number of factors beyond TPACK subdomains, including but are not limited to: students' learning needs, school philosophy, physical and technological features of classroom, demographic characteristics of students, and students' language proficiency levels. In addition, Kelly[21] highlights the importance of the interactions of these factors with each other and with other elements, depending on the subject area.

As for this study and from science teaching perspective, it was highly important for the participants to bring different contexts to the training such as their understanding of nature of science, teaching philosophy, students' perceptions of learning of science, their understanding of technology integration within inquiry, and technology affordances. Although, the participants some issues around their philosophy of teaching science and schools' affordances of technology, they apparently failed to effectively connect these issues with their overall development of TPACK. One way to explain this failure is the fact that the participants have no experience with inquiry models prior the training. In fact, only 2 participants indicated that they used some form of inquiry in their instruction. Studies of science teachers' instructional applications of educational technologies suggest that developing sophisticated level of TPACK requires adequate understanding of the boundaries, challenges, constrains, and issues pertaining the inquiry models $[7,22,24]$. Thereby, teachers should be able to identify the technology features and properties that are able to resolve these challenges or constrains to make science learning more accessible to students [23].

\subsection{Opportunities Offered to Design Technology-based Activities}

What aspects of the teaching strategies afford opportunities to incorporate TPACK in designing technology-based inquiry activities?

The participants' attempts to design technology-based inquiry activities focused solely on one model of inquiry (i.e., $5 \mathrm{E}$ learning cycle) and one type of technology (i.e., PhET simulations). After experiencing $5 \mathrm{E}$ activities, many of the EIM participants developed an adequate level of understanding about how 5E activities were implemented and facilitated without recognizing the importance of contextualizing these activities into their instructional practices. On one hand, the participants recognized different aspects of inquiry such as testing hypothesis and making systematic observations, but they were unable to design inquiry-based activities that would account for their school and students' context. This finding was supported by the descriptive statistics of TIAR scores. The descriptive statistics indicated that the participants mean scores were lowest in two specific TPACK-assessment criteria: the compatibility with curriculum goals and instructional strategy, and learning objectives and technology. On the other hand, the EIM participants couldn't negotiate their 
understanding of TPACK in designing technology-based activities. This finding suggests that the participants needed to think more flexibly and less attached to the content of TPACK. They should have thought carefully how to construct TPACK knowledge within their current thinking. Consequently, many of participants were strongly bounded to the structure of the training without fully connecting their learning with their teaching practice. As a result, the participants were able to develop TPACK in isolation from their school or students' context. In relation to this, Niess[25] brought clarity to TPACK as a way of thinking strategically while involved in planning, organizing, and critiquing for specific student needs, specific content, and specific classroom situations. $\mathrm{He}$ added that developing understanding of the relationships between technology, pedagogy, and content matter is not sufficient to support teacher's abilities to plan for a sound technology-based learning activity. Teachers need to develop pedagogical and technological reasoning that integrates what teachers know about when, where, and how to integrate technology in a series of learning events [7]. This reasoning process is essential in the development of strategic thinking-the thinking that is developed during the continuous reflection on one's learning experience.

\section{Conclusions}

This study was conducted in to the need to understand how to prepare teachers to appropriately integrate technology into teaching and learning of science. The purpose of this study was to determine how to prepare teachers to take into account the pedagogical and content uses of technology to inform the designing of inquiry-based learning activities. This study utilized the theoretical lens of Situated Cognitive Theory to analyze the learning context, and the TPACK framework to analyze the knowledge components that teachers developed. This study was undertaken in response to the growing calls from the educational technology community for more research needed to help teachers develop TPACK to integrate technology into teaching and learning in a particular area of science. A gap had emerged in the community's understanding of this construct because the vast majority of educational technology training has been focused on introducing teachers to technology within the context of computer literacy. Therefore, this study sought to begin addressing this gap by utilizing EIM strategy to examine how to support teachers' pedagogical reasoning and decision-making in the complexity of technology integration in the science classroom.

The findings suggested that experiencing the $5 \mathrm{E}$ learning cycle may help teachers to develop better understanding of the dynamic interrelationships between technology, pedagogy, and content knowledge. However, understanding these types of relationships (i.e., developing TPACK construct) does not necessarily mean that teachers can certainly develop ability to design technology-based inquiry activities. In this study, the TIAR scores showed that, in average, the participants' lesson plans lacked appropriate justifications to the technology selections as a rational to achieve the target curriculum goals. Further, the TIAR scores suggested that the participants' planning choice of technology, teaching method, and science content were carefully fitted together in their lesson plans. These findings suggest that, teachers should be provided with opportunities to negotiate their TPACK to better anticipate and plan for what would likely happen during a technology-medaited inquiry-based instruction.

This study was undertaken to offer other researchers an opportunity to consider how $5 \mathrm{E}$ activities was utilized in action within the context of TPACK-specific training. Further investigations are needed to examine the development of teachers' TPACK in a longer professional development program including lesson planning and classroom teaching. Also, it will be interesting to determine how teachers' TPACK influences student learning of science. Also, further research should consider having teachers learn in cooperative groups, so the social interaction perspective of Situated Cognition Theory could be examined more explicitly. Finally, gender differences and other individual differences such as differences in learning styles, language proficiency levels, and culture differences were not captured in this study.

\section{Acknowledgements}

I am very grateful to Mr. Mehmet Filiz for setting up the online version of Pathfinder Network Scaling tool, and taking care of the technical aspects of the data management. 


\section{Appendix A}

\section{Experiencing Inquiry Model: Lesson Plan}

Part 1

\begin{tabular}{|c|c|}
\hline Main task: Preparing the participants for the workshop & Time: 2 hours \\
\hline $\begin{array}{l}\text { Resources: } \\
\text { - Letter of Information } \\
\text { - Consent Form } \\
\text { - Learner's Guide } \\
\text { - Pathfinder Network Scaling tool } \\
\text { - PhET Circuit Construction Kit simulation } \\
\text { - Laptops } \\
\text { - Internet connection } \\
\text { - Lab equipment: Electric circuit tool kit } \\
\text { - Grade } 6 \text { Textbook } \\
\text { - YouTube clips }\end{array}$ & \\
\hline $\begin{array}{l}\text { Instructional Strategy: } \\
\text { Direct instruction, demonstration, group discussion, and }\end{array}$ & ded-inquiry \\
\hline $\begin{array}{l}\text { Objectives: } \\
\text { At the end of this day, the participants should be able to: } \\
\text { - Recognize the research objectives and procedures } \\
\text { - Describe the main features and functions of the PhET } \\
\text { Circuit Construction Kit simulation } \\
\text { - Develop necessary skills for constructing electric } \\
\text { circuits with PhET simulations } \\
\text { - Demonstrate basic understand of the principles of } \\
\text { electricity and electric circuits } \\
\text { - Recognize the main principles of 5E learning cycle } \\
\text { - Recognize the idea of representing one's knowledge } \\
\text { - Complete the pre-test }\end{array}$ & $\begin{array}{l}\text { Procedures: } \\
\text { The researcher will: } \\
\text { - demonstrate the research objectives and procedures } \\
\text { - clarify the data collection procedures } \\
\text { - state the participants' rights with regard to the protection of private information, } \\
\text { and rights to withdraw from the study at any time } \\
\text { - organize the participants in small groups, and distribute the codes } \\
\text { - introduce the learning expectations } \\
\text { - describe the basic principles of electricity, construction of electric circuits, and } \\
\text { - basic concepts of computer simulation } \\
\text { - introduce the phases of } 5 \mathrm{E} \text { learning cycle as a manifest of inquiry-based learning } \\
\text { - structure via Pathfinder Network Scaling } \\
\text { - adminify the TPACK concepts the participants are going to rate }\end{array}$ \\
\hline
\end{tabular}

Part 2

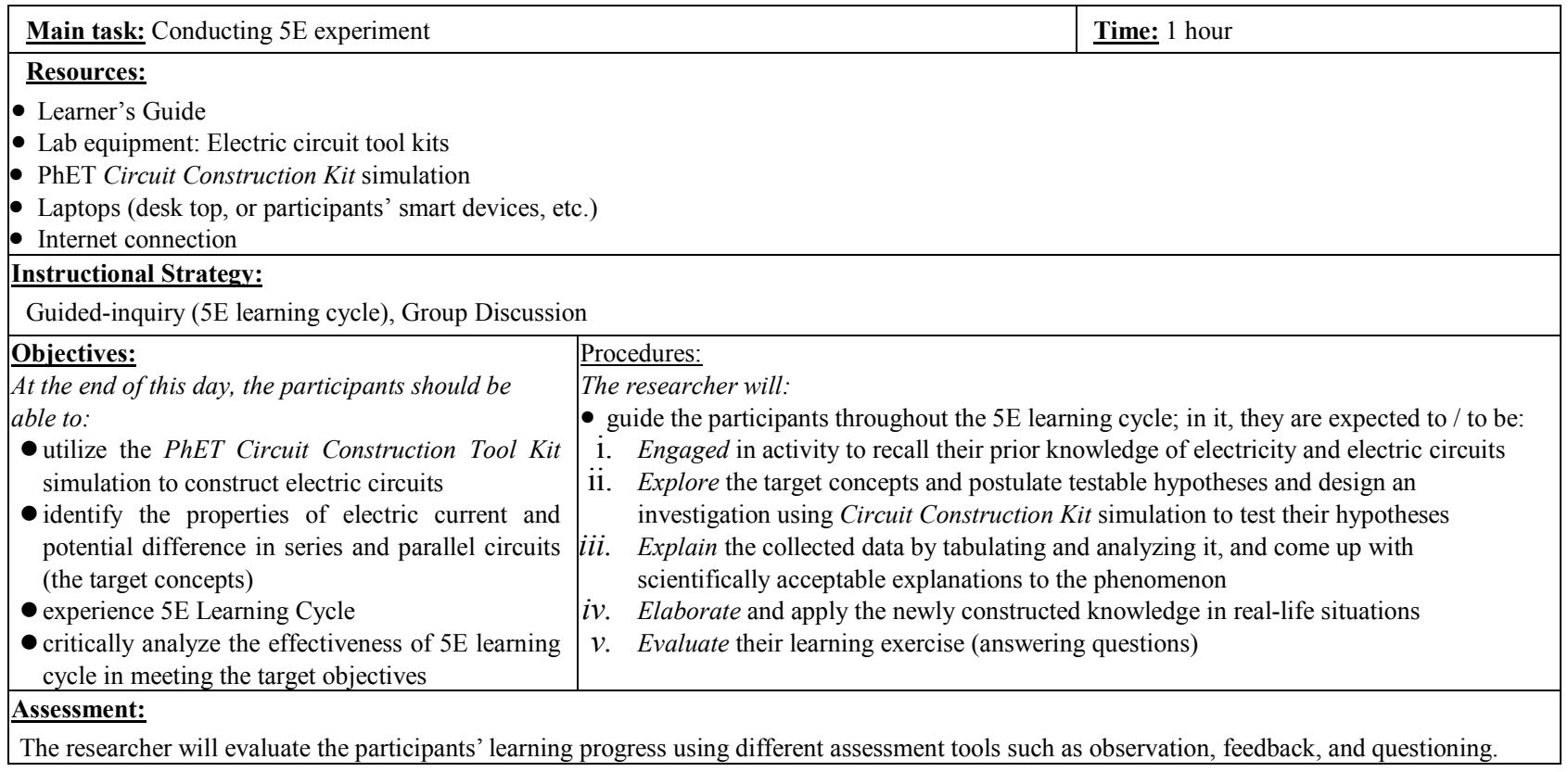


Part 3:

\begin{tabular}{|c|c|}
\hline Main task: analyzing the pedagogical uses of technolo & Time: 2 hours \\
\hline $\begin{array}{l}\text { Resources: } \\
\text { - Learner's Guide } \\
\text { - Electric circuit tool kits } \\
\text { - PhET Circuit Construction Kit simulation } \\
\text { - Pathfinder Network Scaling tool } \\
\text { - Laptops } \\
\text { - Internet connection } \\
\end{array}$ & \\
\hline Instructional Strategv: Group discussion & \\
\hline $\begin{array}{l}\text { Objectives: } \\
\text { At the end of this day, the participants should be able } \\
\text { to: } \\
\text { - recognize different student-centered learning } \\
\text { models } \\
\text { - recognize the benefits of using computer simulation } \\
\text { in enhancing students' understanding of the } \\
\text { construction of electric circuits } \\
\text { - identify the challenges of teaching electricity } \\
\text { through 5E and computer simulation } \\
\text { - recognize different technological tools that are } \\
\text { commonly used in science instruction } \\
\text { - discuss the pedagogical necessity as a rational to } \\
\text { implement computer technology } \\
\text { - discuss the challenges that might be encountered } \\
\text { while teaching and learning with technology } \\
\text { - suggest how these challenges can be overcome } \\
\text { design a technology-mediated inquiry-based } \\
\text { learning activity }\end{array}$ & $\begin{array}{l}\text { Procedures: } \\
\text { The researcher will: } \\
\text { - briefly describe different inquiry learning models (e.g., POE, 3-face cycle, discovery } \\
\text { learning) that are used in science instruction } \\
\text { - describe technological tools that are commonly used to facilitate inquiry learning } \\
\text { models } \\
\text { - engage the participants in group discussion in order to analyze the role of technology as } \\
\text { a rational in meeting the content objectives } \\
\text { - engage the participants in group discussion in order to analyze the role of technology, in } \\
\text { their precedent 5E activities, as a rational in meeting the pedagogical objectives } \\
\text { - facilitate the discussion by posing questions like: } \\
\text { i. In what ways computer technology is beneficial to enhance learning and teaching } \\
\text { through inquiry? } \\
\text { ii. What are the areas in which the computer technology is likely to fall short? } \\
\text { iii. What are the drawbacks of inquiry learning, if any, within the context of teaching } \\
\text { and learning of science? } \\
\text { - administer the post-test (using Pathfinder Network Scaling) } \\
\text { - ask the participants to design inquiry-based activity (or work on a previously designed } \\
\text { activity) }\end{array}$ \\
\hline Assessment: & \\
\hline
\end{tabular}




\section{Appendix B}

\section{Implementation protocol for EIM strategy}

\begin{tabular}{|c|c|c|c|c|}
\hline \multicolumn{5}{|l|}{ Session 1} \\
\hline Date/Time & Task/Justification & Resources/Procedures & What could go wrong? & Contingency/Avoidance plan \\
\hline $15 \mathrm{~min}$. & $\begin{array}{l}\text { Pre-Task (1): } \\
\text { - Introducing the research project } \\
\text { Distributing and signing the } \\
\text { - } \text { Orgs } \\
\text { small groups } \\
\text { Justification: } \\
\text { Inform the participants about the } \\
\text { project and get their consent to go } \\
\text { ahead on the data collection } \\
\text { procedures }\end{array}$ & $\begin{array}{l}\text { Resources: } \\
\text { Learner's Guide, Information Letter, Consent Forms, Name tags } \\
\text { Procedures, I will: } \\
\text { 1. Use the information letter to describe the research objectives and procedures; in } \\
\text { the description, include the idea of recognizing the interrelationships } \\
\text { between technology, pedagogy, and technology } \\
\text { 2. Ask the participants to hand in the Consent forms signed; } \\
\text { 3. Remind the participants that the main scope of this workshop is not intended } \\
\text { to introduce something new, rather it's aimed to provide you with } \\
\text { opportunities to understand the interrelationships between technology, } \\
\text { pedagogy, and technology. }\end{array}$ & $\begin{array}{l}\text { - Some participants } \\
\text { may come late or } \\
\text { don't show up at all; } \\
\text { This task may take } \\
\text { longer than } \\
\text { anticipated }\end{array}$ & $\begin{array}{l}\text { - Participants who are coming } \\
\text { late, talk to them individually; } \\
\text { To avoid any delay, prepare } \\
\text { all the materials, settings, } \\
\text { resources, etc. ahead of time. } \\
\text { To do that, arrive early, and } \\
\text { prepare the classroom } 30 \text { min. } \\
\text { prior the beginning of the } \\
\text { session. Any paperwork } \\
\text { should be done as early as } \\
\text { possible. } \\
\text { To save more time, send the } \\
\text { information letter out so we } \\
\text { don't waste time in } \\
\text { explicating the research } \\
\text { procedures. }\end{array}$ \\
\hline $10 \mathrm{~min}$. & $\begin{array}{l}\text { Pre-Task (2): } \\
\text { - Short introduction to } \\
\quad \text { educational technology } \\
\text { Justifications: } \\
\text { Leading-in }\end{array}$ & $\begin{array}{l}\text { Resources: } \\
\text { PowerPoint presentation } \\
\text { Procedures, I will: } \\
\text { 1. Elaborate on the basic components of TPACK and the interrelationship } \\
\text { between these components. (PP) } \\
\text { 2. Go through the overall expectations and the specific expectations } \\
\text { 3. Go through Today's agenda } \\
\text { 4. Answer any question posed by the participants before the start } \\
\text { 5. Ask the participants to create groups of } 3 \text { members. }\end{array}$ & $\begin{array}{l}\text { - The speech may take } \\
\text { longer time } \\
\text { - The participants may } \\
\text { pose more questions }\end{array}$ & $\begin{array}{l}\text { - Discuss very limited points } \\
\text { (e.g., IT, TPACK, and why } \\
\text { developing TPACK) }\end{array}$ \\
\hline $20 \mathrm{~min}$. & $\begin{array}{l}\text { Task 1: } \\
\text { Describe the basic principles of } \\
\text { electricity and electric circuit as } \\
\text { required by the Ontario Science \& } \\
\text { Technology Curriculum - Grad } 6 \text {. } \\
\text { Justification: } \\
\text { Prerequisite to complete Pathfinder } \\
\text { Network Scaling }\end{array}$ & $\begin{array}{l}\text { Resources: } \\
\text { YouTube clip, Grade } 6 \text { Textbook, copies of science curriculum } \\
\text { Procedures, I will: } \\
\text { 1. Introduce the concepts of electricity. In it, I will ask the participants what do } \\
\text { they know about electricity and whether they teach these concepts in their } \\
\text { regular classes (PP) } \\
\text { 2. Show a YouTube clip that describes the fundamental concepts of electric } \\
\text { circuits } \\
\text { 3. Ask the participants to complete "Constructing a Simple Circuit" activity, } \\
\text { using concrete objects such as: batteries, bulb, connecting wires, switch, etc. } \\
\text { 4. Summarize the basic idea of current, potential difference, and electric circuits } \\
\text { (use Grade } 6 \text { Textbook as a reference and PP) } \\
\text { 5. Organize the above documents in the guide }\end{array}$ & $\begin{array}{l}\text { - The participants } \\
\text { may ask too many } \\
\text { questions. } \\
\text { Resources may not } \\
\text { be available such as } \\
\text { electric circuit tool } \\
\text { kits. }\end{array}$ & $\begin{array}{l}\text { - Prepare a YouTube clip that } \\
\text { describes the concepts the } \\
\text { best. In it, there should be a } \\
\text { verbal description of the topic } \\
\text { as well as a visual aid activity. } \\
\text { The clip should not take more } \\
\text { than 5-8 min. } \\
\text { - Connect the YouTube clip with } \\
\text { the specific expectations of the } \\
\text { curriculum. } \\
\text { - Use Grade } 6 \text { Textbook to } \\
\text { elaborate more on the topic or } \\
\text { explain other concepts. } \\
\text { If the electric circuit tools kits } \\
\text { is not available, blend task } 1 \\
\text { and } 2\end{array}$ \\
\hline
\end{tabular}




\begin{tabular}{|c|c|c|c|c|}
\hline $20 \mathrm{~min}$. & $\begin{array}{l}\text { Task 2: } \\
\text { Introducing PhET Circuit } \\
\text { Construction Kit simulation } \\
\text { Justification: } \\
\text { Prerequisite to complete Pathfinder } \\
\text { Network Scaling }\end{array}$ & $\begin{array}{l}\text { Resources: } \\
\text { Laptops or desktops, Internet connection, PhET Website } \\
\text { Procedures, I will: } \\
\text { 1. Briefly clarify what computer simulation is, and what PhET simulations are } \\
\text { (PP). } \\
\text { 2. Ask the participants: are you using PhET simulations in your classroom } \\
\text { teaching? } \\
\text { 3. Ask the participants to login to their computers (or from the portable flash } \\
\text { memory) and go to www.phet.clorado.edu } \\
\text { 4. Go through the main sections of the PhET simulations website } \\
\text { 5. With minimum guidance, ask the participants to complete "PhET Circuit } \\
\text { Construction" activity, so they could be more familiar with electric circuits } \\
\text { construction via PhET simulation }\end{array}$ & $\begin{array}{l}\text { - Java software may } \\
\text { not be installed in the } \\
\text { computers. } \\
\text { Slow Internet } \\
\text { connection, and } \\
\text { hence unable to } \\
\text { complete Task } 2 \text { in } \\
\text { time } \\
\text { Difficulties to go } \\
\text { about the simulation }\end{array}$ & $\begin{array}{l}\text { - Make sure Java software is } \\
\text { installed in the school's } \\
\text { computers. Alternatively, as } \\
\text { the participants to bring their } \\
\text { laptops with Java installed. } \\
\text { - Save the Circuit Construction } \\
\text { simulation in a flash memory. } \\
\text { Use this copy in case there are } \\
\text { some difficulties in the } \\
\text { Internet connection. } \\
\text { Walk the participants through } \\
\text { the login process and how to } \\
\text { locate the PhET simulations. }\end{array}$ \\
\hline $15 \mathrm{~min}$. & $\begin{array}{l}\text { Task 3: } \\
\text { Introducing } 5 \mathrm{E} \text { learning cycle } \\
\text { Justification: } \\
\text { Prerequisite to complete Pathfinder } \\
\text { Network Scaling }\end{array}$ & $\begin{array}{l}\text { Resources: } \\
\text { PowerPoint presentation, YouTube clip } \\
\text { Procedures, I will: } \\
\text { 1. Briefly, discuss with the class the types of inquiry instructions used in schools. } \\
\text { 2. Ask the participants if they have used } 5 \mathrm{E} \text { in their teaching? } \\
\text { 3. Use PowerPoint slides to demonstrate the phases of } 5 \mathrm{E} \text { learning cycle, include } \\
\text { in the PP a brief description of the } 5 \text { phases (PP) } \\
\text { 4. Show a YouTube clip, if needed }\end{array}$ & $\begin{array}{l}\text { - The participants may } \\
\text { not so familiar to } 5 \mathrm{E} \\
\text { learning cycle } \\
\text { The participants may } \\
\text { get confused or } \\
\text { overwhelmed }\end{array}$ & $\begin{array}{l}\text { Describe 5Es in a very } \\
\text { simple manner. They are } \\
\text { going to learn about it any } \\
\text { way. }\end{array}$ \\
\hline $10 \mathrm{~min}$. & $\begin{array}{l}\text { Task 4: } \\
\text { Introducing Pathfinder Network } \\
\text { Scaling tool } \\
\text { Justification: } \\
\text { Inform the participants how their } \\
\text { knowledge structure can be assessed; } \\
\text { and hence, be able to make sense } \\
\text { when they relate the concepts of } \\
\text { electricity, 5E, and PhET simulation. } \\
\text { Administering the pre-test } \\
\text { Justification: } \\
\text { The pre-test will illustrate the } \\
\text { participants' knowledge structure } \\
\text { prior the intervention. The pre-test } \\
\text { will be considered as a covariate in } \\
\text { order to normalize any differences } \\
\text { between the groups. }\end{array}$ & $\begin{array}{l}\text { Resources: } \\
\text { Pathfinder Network Scaling (portable flash memory) } \\
\text { Procedures, I will: } \\
\text { 1. Briefly describe the concepts of knowledge structure and how it's assessed by } \\
\text { Pathfinder Network Scaling (PP). } \\
\text { 2. Ask the participants to use the Example to rate the relatedness of familiar set } \\
\text { of words such as: Ostrich, Reptile, Snake, and Bird } \\
\text { 3. If there is enough time, let the participants use Pathfinder Network Scaling and } \\
\text { view their knowledge structures as pertaining to these concepts/words } \\
\text { (recommended). } \\
\text { 4. Ask the participants to rate the relatedness of } 36 \text { pairs of concepts pertaining to } \\
\text { Electricity, 5E, and computer simulation (pre-test) }\end{array}$ & $\begin{array}{l}\text { - Unable to complete } \\
\text { Task } 3 \text { in time } \\
\text { Technical issues } \\
\text { related to Pathfinder } \\
\text { tool }\end{array}$ & $\begin{array}{l}\text { - Describe the concept of } \\
\text { assessment of knowledge } \\
\text { structure in a very simple way. } \\
\text { Be aware of the technical } \\
\text { problems } \\
\text { In this training session, group } \\
\text { the concepts in a } \\
\text { questionnaire, and ask the } \\
\text { participants to rate the } \\
\text { relatedness of the concepts } \\
\text { using a hard copy. }\end{array}$ \\
\hline $60 \mathrm{~min}$. & $\begin{array}{l}\text { Task 5: } \\
\text { Conducting an inquiry experiment } \\
\text { using 5E learning cycle: Engage, } \\
\text { Explore, Explain, Elaborate, and } \\
\text { Evaluate }\end{array}$ & $\begin{array}{l}\text { Resources: } \\
\text { Learner's Guide, Electric circuit tool kits }(5 \text { sets), PhET simulation } \\
\text { Procedures, I will: } \\
\text { 1. Ask the participants to form their groups. } \\
\text { 2. Distribute learning activity \# } \mathbf{5} \text { (the participants should keep the hand outs in }\end{array}$ & $\begin{array}{l}\text { - The participant may } \\
\text { skip the phases and } \\
\text { don't follow the } \\
\text { learning sequence as } \\
\text { planned. }\end{array}$ & $\begin{array}{l}\text { - Emphasize the fact that the } \\
\text { participants are expected to } \\
\text { act like Grade } 6 \text { students and } \\
\text { they will be given another } \\
\text { opportunity to act like science } \\
\text { teachers. }\end{array}$ \\
\hline
\end{tabular}




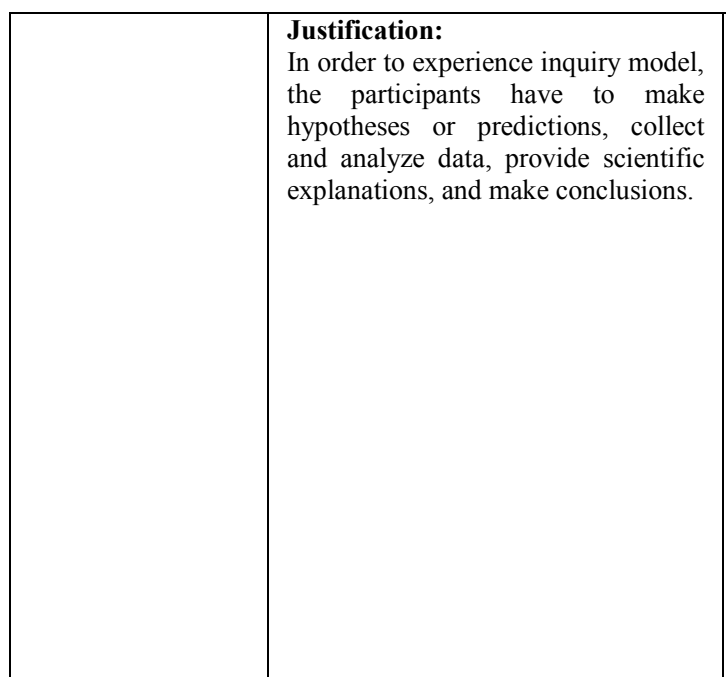

their folder).

1) In Engage phase, ask the participants to discuss a scenario involving how the brightness of bulbs would be different in series and parallel connections. Present a real-life situation where bulbs are connected in series and parallel; ask questions, pose problems, and assess prior knowledge. (10 min.)

ii) In Explore phase, ask the participants to predict (or make hypotheses) the level of brightness of light lamps in series and parallel circuits. The participants are expected to design and conduct an inquiry, collecting data via PhET simulation, organize and analyze the gathered data. (30min.)

iii) In Explain phase, ask the participants to analyze the data and come up with scientifically acceptable explanations to their data; ask them to share their ideas and comments; remind the participants to go back to the simulation if they want to confirm or test their ideas; and conclude the findings. (20 min.)

iv) In Elaborate phase, ask the participants to respond to the questions; at the end of this phase, ask the participants to share their ideas and comments with the class; remind the participants to go back to the simulation if they want to confirm their answers.

v)In Evaluate phase, ask the participants to solve few questions to be able to evaluate their learning. In addition, the participants should be assessed throughout the experiment (15 min.).
- $\quad$ The participants may go directly to Explain phase without making predictions or hypotheses.

- The participants may start acting as science teachers and forget to focus on completing the tasks
- $\quad$ Allow some kind of feedback between $5 \mathrm{E}$ phases. Thereby, make sure the participants are following the guidelines and on task.

Go around and respond to the participants' questions, difficulties, or inquiries.

- Always remind the participants that we will analyze the $5 \mathrm{E}$ activities later on.

\begin{tabular}{|c|c|c|c|c|c|c|}
\hline \multicolumn{7}{|l|}{$\underline{\text { Session } 2}$} \\
\hline $70 \mathrm{~min}$. & $\begin{array}{l}\text { Task 6: } \\
\text { Discussing the role of technology as } \\
\text { a rational of pedagogical and content } \\
\text { objectives } \\
\text { (Analysis and Assessment) } \\
\text { Justification: } \\
\text { The participants are expected to act } \\
\text { like professionals and analyze the } \\
\text { effectiveness of their precedent } \\
\text { learning activities }\end{array}$ & \multicolumn{2}{|c|}{$\begin{array}{l}\text { Resources: } \\
\text { Grade } 6 \text { Textbook, PhET simulations, Electric Circuit Tool kits } \\
\text { Procedures, I will: } \\
\text { 1. Ask the participants to organize themselves in groups based on their grade levels } \\
\text { (3 members in each group). } \\
\text { 2. Briefly describe different models of inquiry learning; put more emphases on } \\
\text { teacher and student's roles (PP) } \\
\text { 3. Briefly describe the types of technologies used for teaching and learning of science } \\
\text { (PP) } \\
\text { 4. Ask the participants to complete Learning Task \# 6. In it, they are expected to act } \\
\text { like science teachers and discuss their precedent experience. } \\
\text { 5. Clarify the issues (1-3), if needed (read page } 196 \text { on McCrory) (PP). } \\
\text { 6. Ask the participants to think about the PhET simulation, and whether it's } \\
\text { effectiveness in completing the learning tasks. They can also go back to the } \\
\text { simulation to gain better understanding of the issues, if needed. } \\
\text { 7. Each group will be assigned to one topic, and in the end they discuss their } \\
\text { topic with the class. } \\
\text { 8. At the end of the discussion period, summarize the participants' presentations; } \\
\text { highlight any interesting points, critical issues, or relevant challenges to be } \\
\text { addressed. }\end{array}$} & \multicolumn{2}{|c|}{$\begin{array}{l}\text { - The participants may } \\
\text { discuss some aspects of } \\
\text { their own learning. } \\
\text { They may discuss how } \\
\text { easy/difficult to perform } \\
\text { the inquiry tasks; or } \\
\text { They may express some } \\
\text { kind of satisfactions } \\
\text { because they are able to } \\
\text { finish the tasks in time. }\end{array}$} & $\begin{array}{l}\text { - Emphasize the fact that } \\
\text { this is the time to act like } \\
\text { professional teachers. } \\
\text { Any discussion about the } \\
\text { activities should be } \\
\text { related to } 6 \text { Graders and } \\
\text { not themselves. } \\
\text { - Ask the participants to } \\
\text { analyze the effectiveness } \\
\text { of the learning activities } \\
\text { instead of discussing their } \\
\text { own learning. } \\
\text { Learning Task } 5 \text { should } \\
\text { be carefully designed to } \\
\text { fulfill the points stated } \\
\text { above. }\end{array}$ \\
\hline $30 \mathrm{~min}$. & $\begin{array}{l}\text { Task 7: } \\
\text { critically analyzing the precedent } \\
\text { learning activities }\end{array}$ & \begin{tabular}{|l|} 
Resources: \\
Learner's Guide, Electric circuit tool kits (5 sets), PhET simulation,
\end{tabular} & $\begin{array}{l}- \text { The } \\
\text { may fo } \\
\text { relation } \\
\text { between } \\
\text { and }\end{array}$ & $\begin{array}{l}\text { participants } \\
\text { cus on few } \\
\text { ships } \\
\text { PK, TK, } \\
\text { CK; and }\end{array}$ & $\begin{array}{l}\text { - The Learning } \\
\text { questions. Th } \\
\text { TPACK inte } \\
\text { and TPACK) }\end{array}$ & $\begin{array}{l}\text { Task } 6 \text { should include leading } \\
\text { e leading questions should cover } \\
\text { sections (i.e., TPK, TCK, PCK, }\end{array}$ \\
\hline
\end{tabular}




\begin{tabular}{|c|c|c|c|c|c|}
\hline & $\begin{array}{l}\text { Justification: } \\
\text { This learning opportunity aims at } \\
\text { engaging the participants in } \\
\text { discussion to understand the } \\
\text { interrelationships between 5Es (PK), } \\
\text { computer simulation (TK), and } \\
\text { electric circuit (CK). As a result, } \\
\text { they should be able to develop } \\
\text { TPACK. }\end{array}$ & \multicolumn{2}{|c|}{$\begin{array}{l}\text { Procedures, I will: } \\
\text { 1. Ask the participants to go back to their grade-based groups. } \\
\text { 2. Ask the participants to complete Learning Task \# 7. In it, the } \\
\text { participants are expected to respond to specific questions and } \\
\text { discuss the rational granted to the computer technology in } \\
\text { meeting pedagogical goals and learning objectives (issues } 1-3 \text { ). } \\
\text { 3. Walk around and observe the responses, questions, ideas, or } \\
\text { comments on their tasks. }\end{array}$} & $\begin{array}{l}\text { overlook other ones. } \\
\text { The participants } \\
\text { may spend long time } \\
\text { on talking/chatting } \\
\text { without getting to } \\
\text { solid conclusions. }\end{array}$ & $\begin{array}{l}\text { - I should facilitate the discussion in a way that } \\
\text { helps the participants to much of their } \\
\text { cognitive time more effectively. To do that, I } \\
\text { should be firm on timing, finishing tasks in } \\
\text { time, allowing specific questions, wrapping up } \\
\text { discussions, writing the main points on the } \\
\text { board, extracting themes and issues, and } \\
\text { responding to 'what if' scenarios. }\end{array}$ \\
\hline $25 \mathrm{~min}$. & \multicolumn{2}{|c|}{$\begin{array}{l}\text { Task 8: } \\
\text { Administering the pre-test } \\
\text { Justification: } \\
\text { The post-test is expected to determine the changes } \\
\text { in the participants' structure of knowledge that } \\
\text { could have occurred during the intervention. The } \\
\text { post-test should be conducted immediately after } \\
\text { the intervention to avoid the influence of a third } \\
\text { variable (internal validity). }\end{array}$} & 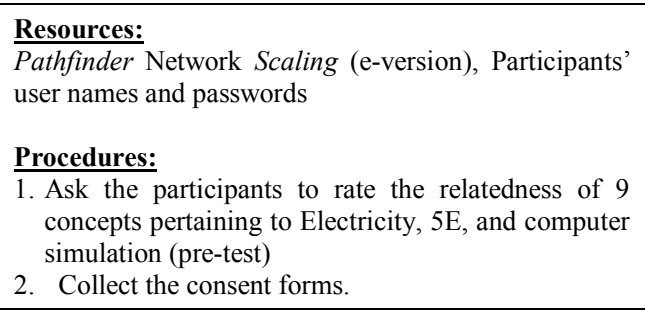 & $\begin{array}{l}\text { Technical issues } \\
\text { related to } \\
\text { Pathfinder tool } \\
\text { The participants } \\
\text { may gain some } \\
\text { kind of testing } \\
\text { effect. }\end{array}$ & $\begin{array}{l}\text { - } \quad \text { Be aware of the technical problems } \\
\text { Group the target concepts in a questionnaire, } \\
\text { and ask the participants to rate the relatedness } \\
\text { of the concepts using a hard copy. } \\
\text { - Reorganize the concepts } \\
\text { - Add the same pair of concepts more than once. } \\
\text { Test the correlation effect among those } \\
\text { particular concepts. In consistent ratings will be } \\
\text { eliminated. }\end{array}$ \\
\hline $50 \mathrm{~min}$. & \multicolumn{2}{|c|}{$\begin{array}{l}\text { Task 9: } \\
\text { designing a technology-mediated inquiry-based } \\
\text { learning activity } \\
\text { Justification: } \\
\text { This is an opportunity to apply the participants' } \\
\text { understanding of TPACK in designing learning } \\
\text { activities. It's important to examine the } \\
\text { participants' abilities to incorporate their } \\
\text { understanding of TPACK in one of their teaching } \\
\text { practices. Simply because, developing TPACK } \\
\text { doesn't necessarily lead to an effective integration } \\
\text { of technology in science instruction. }\end{array}$} & $\begin{array}{l}\text { Resources: } \\
\text { Exercise Sheet } \\
\text { Procedures: } \\
\text { Ask the participants to complete the exercise. In it, } \\
\text { they are expected to design a technology-based } \\
\text { learning activity. They can work on a previously } \\
\text { designed activity or design a new one. Their design } \\
\text { should integrate a technological tool or tools, or } \\
\text { may be no technology at all. Their design should } \\
\text { include the following elements: } \\
\text { Topic, target objectives, resources, teaching approach, } \\
\text { cognitive tools (technology vs lab), assessment tools, } \\
\text { procedures, and the rational granted to technology and } \\
\text { teaching approach in meeting learning objectives. }\end{array}$ & $\begin{array}{l}\text { The participants } \\
\text { may not be able to } \\
\text { finish this task, or } \\
\text { parts of it, in time. }\end{array}$ & $\begin{array}{l}\text { - Ask the participants to bring to the class a } \\
\text { previously designed activity to work on it. } \\
\text { The participants are not obliged to use a specific } \\
\text { content, or specific teaching strategy. } \\
\text { Ask the participants to focus on the reasoning } \\
\text { and decision-making parts. For example, what } \\
\text { features make a specific technology the best } \\
\text { choice for their design and why; etc. } \\
\text { In the Exercise Sheet, include templates, fill up } \\
\text { the blanks, leading questions, etc. }\end{array}$ \\
\hline $15 \mathrm{~min}$. & \multicolumn{2}{|c|}{$\begin{array}{l}\text { Task: } \\
\text { Focus group interview and debriefing } \\
\text { Justification: } \\
\text { The interview session is expected to describe the } \\
\text { parts of the intervention and post-intervention } \\
\text { exercise that can't be examined by the quantitative } \\
\text { analysis. Also, the interview will allow the } \\
\text { researcher to examine the conditions of the } \\
\text { strategy by which the learners could benefit the } \\
\text { most. }\end{array}$} & $\begin{array}{l}\text { Procedures, I will: } \\
\text { 1. interview the participants for } 15 \text { minutes according } \\
\text { to the following protocol: } \\
\text { 2. debrief the participants and say THANK YOU }\end{array}$ & $\begin{array}{l}\text { - } \quad \text { No show case } \\
\text { The participants } \\
\text { might be } \\
\text { overwhelmed. }\end{array}$ & $\begin{array}{l}\text { - Establish a protocol for the interview (timing, } \\
\text { taping, Q \& A, etc.) } \\
\text { - The interview can be conducted at earlier stage } \\
\text { (e.g., during the exercise). } \\
\text { - } \quad \text { Fire up the interview with leading questions. } \\
\text { - Hear the participants' voices. } \\
\text { - } \quad \text { Allow equal opportunities for all members. }\end{array}$ \\
\hline
\end{tabular}




\section{Appendix C}

Technology Integration Assessment Rubric (TIAR)

\begin{tabular}{|c|c|c|c|c|}
\hline Criteria & 4 & 3 & 2 & 1 \\
\hline $\begin{array}{c}\text { Curriculum Goals and } \\
\text { Technologies } \\
\text { (Curriculum-based technology } \\
\text { use) }\end{array}$ & $\begin{array}{c}\text { Technologies selected for } \\
\text { use in the instructional } \\
\text { plan are strongly aligned } \\
\text { with one or more } \\
\text { curriculum goals }\end{array}$ & $\begin{array}{c}\text { Technologies selected for } \\
\text { use in the instructional } \\
\text { plan are aligned with on } \\
\text { or more curriculum goals }\end{array}$ & $\begin{array}{c}\text { Technologies selected for } \\
\text { use in the instructional } \\
\text { plan are partially aligned } \\
\text { with one or more } \\
\text { curriculum goals }\end{array}$ & $\begin{array}{c}\text { Technologies selected for } \\
\text { use in the instructional } \\
\text { plan are not aligned with } \\
\text { one or more curriculum } \\
\text { goals }\end{array}$ \\
\hline $\begin{array}{c}\text { Instructional Strategies and } \\
\text { Technologies } \\
\text { (Using technology in teaching/ } \\
\text { learning) }\end{array}$ & $\begin{array}{c}\text { Technology use } \\
\text { optimally supports } \\
\text { instructional strategies }\end{array}$ & $\begin{array}{c}\text { Technology use supports } \\
\text { instructional strategies }\end{array}$ & $\begin{array}{c}\text { Technology use } \\
\text { minimally supports } \\
\text { instructional strategies }\end{array}$ & $\begin{array}{c}\text { Technology use does not } \\
\text { support instructional } \\
\text { strategies }\end{array}$ \\
\hline $\begin{array}{c}\text { Technology Selection(s) } \\
\text { (Compatibility with } \\
\text { curriculum goals and } \\
\text { instructional strategies) }\end{array}$ & $\begin{array}{c}\text { Technology use } \\
\text { optimally supports } \\
\text { instructional strategies }\end{array}$ & $\begin{array}{c}\text { Technology selection(s) } \\
\text { are appropriate, but not } \\
\text { exemplary, given } \\
\text { curriculum goal(s) and } \\
\text { instructional strategies }\end{array}$ & $\begin{array}{c}\text { Technology selection(s) } \\
\text { are marginally } \\
\text { appropriate, given } \\
\text { curriculum goal(s) and } \\
\text { instructional strategies }\end{array}$ & $\begin{array}{c}\text { Technology selection(s) } \\
\text { are inappropriate, given } \\
\text { curriculum goal(s) and } \\
\text { instructional strategies }\end{array}$ \\
\hline "Fit" & $\begin{array}{c}\text { Content, instructional } \\
\text { strategies and technology } \\
\text { fit together strongly } \\
\text { within the instructional } \\
\text { plan. }\end{array}$ & $\begin{array}{c}\text { Content, instructional } \\
\text { strategies and technology } \\
\text { fit together within the } \\
\text { instructional plan. }\end{array}$ & $\begin{array}{c}\text { Content, instructional } \\
\text { strategies and technology } \\
\text { fit together somewhat } \\
\text { within the instructional } \\
\text { plan }\end{array}$ & $\begin{array}{c}\text { Content, instructional } \\
\text { strategies and technology } \\
\text { do not fit together within } \\
\text { the instructional plan }\end{array}$ \\
(Content, pedagogy and \\
technology together)
\end{tabular}

(Harris, Grandgenett, \& Hofer, 2010)

\section{Appendix D}

\section{Interview questions for service teachers}

1. As learner, what do you think are the key parts of the teaching strategy that make a good learning opportunity for you? a. In which way did this opportunity (or opportunities) enhance your learning of technology integration?

b. What methods did you use to maximize your learning (if any)?

c. What importance do you place on such strategies to enhance teaching science with technology?

2. What do you think are the important technological competencies (knowledge and skills) for you to properly use technology in classroom?

a. How can you evaluate your own competencies in ICT integration in science teaching?

b. Does this level of ICT integration competency you have, affects your motivation to use ICT in teaching?

c. How do you engage your future students to learn by using ICT?

3. Based on your precedent experience, what do you know about TPACK framework?

a. How do you establish a relationship between technology, pedagogy, and science content?

b. To what extent do you think your understanding of TPACK can be a replica to teaching science with technology?

4. Do you use TPACK as a guide to your activities?

a. In what ways do you use TPACK framework?

b. How can you describe your competency level of on TPACK?

c. What do you consider to be strength and or weaknesses of TPACK framework?

d. To what extent do you think you will be able to use ICT in your teaching after graduation?

5. What is your future plan of enhancing technology integration for your students' class? 


\section{Appendix E}

\section{Pathfinder questionnaire}

\begin{tabular}{|c|c|c|c|}
\hline Concept 1 & Concept 2 & $\begin{array}{c}\text { Select a rating between } 1 \\
\text { (Unrelated) and } 5 \text { (Highly related) }\end{array}$ & $\begin{array}{l}\text { Justify the "Related" and } \\
\text { "Highly related" ratings }\end{array}$ \\
\hline Electric current & Electric circuit & Click here to select & Click here to enter comments \\
\hline Measurement of voltage & Multimedia projector & Click here to select & Click here to enter comments \\
\hline Multimedia projector & PhET Electric Circuit simulation & Click here to select & Click here to enter comments \\
\hline Electric circuit & Multimedia projector & Click here to select & Click here to enter comments \\
\hline Multimedia projector & Testing hypotheses & Click here to select & Click here to enter comments \\
\hline PhET Electric Circuit simulation & $\begin{array}{c}\text { Evaluation of PhET Electric Circuit } \\
\text { simulation }\end{array}$ & Click here to select & Click here to enter comments \\
\hline Electric current & Measurement of voltage & Click here to select & Click here to enter comments \\
\hline $\begin{array}{l}\text { Curriculum expectations related to } \\
\text { Electricity }\end{array}$ & Electric circuit & Click here to select & Click here to enter comments \\
\hline Measurement of voltage & PhET Electric Circuit simulation & Click here to select & Click here to enter comments \\
\hline $\begin{array}{l}\text { Evaluation of PhET Electric } \\
\text { Circuit simulation } \\
\end{array}$ & Student's summative assessment & Click here to select & Click here to enter comments \\
\hline Measurement of voltage & Testing hypotheses & Click here to select & Click here to enter comments \\
\hline PhET Electric Circuit simulation & Student's summative assessment & Click here to select & Click here to enter comments \\
\hline Student's summative assessment & Testing hypotheses & Click here to select & Click here to enter comments \\
\hline Multimedia projector & $\begin{array}{l}\text { Curriculum expectations related to } \\
\text { Electricity }\end{array}$ & Click here to select & Click here to enter comments \\
\hline
\end{tabular}

\begin{tabular}{|c|c|c|c|}
\hline Concept 1 & Concept 2 & $\begin{array}{c}\text { Select between } 1 \\
\text { (unrelated) and } 5 \text { (highly } \\
\text { related) }\end{array}$ & Rational \\
\hline Student's summative assessment & Electric circuit & Click here to select & Click here to enter comments. \\
\hline Measurement of voltage & Student's summative assessment & Click here to select & Click here to enter comments. \\
\hline Measurement of voltage & $\begin{array}{c}\text { Curriculum expectations related to } \\
\text { Electricity }\end{array}$ & Click here to select & Click here to enter comments. \\
\hline Electric current & Multimedia projector & Click here to select & Click here to enter comments. \\
\hline $\begin{array}{c}\text { Evaluation of PhET Electric Circuit } \\
\text { simulation }\end{array}$ & Measurement of voltage & Click here to select & Click here to enter comments. \\
\hline Testing hypotheses & Electric current & Click here to select & Click here to enter comments. \\
\hline $\begin{array}{l}\text { Curriculum expectations related to } \\
\text { Electricity }\end{array}$ & Testing hypotheses & Click here to select & Click here to enter comments. \\
\hline PhET Electric Circuit simulation & Electric circuit & Click here to select & Click here to enter comments. \\
\hline Electric current & $\begin{array}{l}\text { Curriculum expectations related to } \\
\text { Electricity }\end{array}$ & Click here to select & Click here to enter comments. \\
\hline Testing hypotheses & PhET Electric Circuit simulation & Click here to select & Click here to enter comments. \\
\hline Measurement of voltage & Electric circuit & Click here to select & Click here to enter comments. \\
\hline $\begin{array}{l}\text { Curriculum expectations related to } \\
\text { Electricity }\end{array}$ & Student's summative assessment & Click here to select & Click here to enter comments. \\
\hline $\begin{array}{c}\text { Evaluation of PhET Electric Circuit } \\
\text { simulation }\end{array}$ & Testing hypotheses & Click here to select & Click here to enter comments. \\
\hline Electric current & $\begin{array}{l}\text { Evaluation of PhET Electric Circuit } \\
\text { simulation }\end{array}$ & Click here to select & Click here to enter comments. \\
\hline
\end{tabular}

\begin{tabular}{|c|c|c|c|}
\hline Concept 1 & Concept 2 & $\begin{array}{c}\text { Select between } 1 \\
\text { (unrelated) and } 5 \text { (highly } \\
\text { related) }\end{array}$ & Rational \\
\hline Multimedia projector & Student's summative assessment & Click here to select & Click here to enter comments. \\
\hline Electric current & PhET Electric Circuit simulation & Click here to select & Click here to enter comments. \\
\hline $\begin{array}{c}\text { Evaluation of PhET Electric Circuit } \\
\text { simulation }\end{array}$ & $\begin{array}{l}\text { Curriculum expectations related to } \\
\text { Electricity }\end{array}$ & Click here to select & Click here to enter comments. \\
\hline Electric current & Student's summative assessment & Click here to select & Click here to enter comments. \\
\hline Multimedia projector & $\begin{array}{c}\text { Evaluation of PhET Electric Circuit } \\
\text { simulation }\end{array}$ & Click here to select & Click here to enter comments. \\
\hline Electric circuit & Testing hypotheses & Click here to select & Click here to enter comments. \\
\hline $\begin{array}{l}\text { Curriculum expectations related to } \\
\text { Electricity }\end{array}$ & PhET Electric Circuit simulation & Click here to select & Click here to enter comments. \\
\hline Electric circuit & $\begin{array}{c}\text { Evaluation of PhET Electric Circuit } \\
\text { simulation }\end{array}$ & Click here to select & Click here to enter comments. \\
\hline
\end{tabular}




\section{Appendix F}

\section{Lesson Plan (Template)}

Title:

\begin{tabular}{|c|c|c|c|c|}
\hline \multirow{2}{*}{$\begin{array}{l}\text { Grade: } \\
\text { Length: }\end{array}$} & Click here to enter te & \multicolumn{3}{|l|}{ Strand/topic: } \\
\hline & & & & Code: \\
\hline \multicolumn{4}{|c|}{ Target or Curriculum Objectives (what will students be able to do/know by the end of the activity) } & $\begin{array}{l}\text { Teaching Method (Tick all that apply) } \\
\bigotimes \quad \text { Demonstration (Didactic) } \\
\bigotimes \text { Guided Inquiry } \\
\bigotimes \text { Open Inquiry } \\
\square \text { Lecture } \\
\square \text { Group discussion } \\
\square \text { Others (specify): }\end{array}$ \\
\hline \multicolumn{2}{|c|}{$\begin{array}{c}\text { Resources } \\
\text { Equipment and materials (if } \\
\text { needed) }\end{array}$} & $\begin{array}{l}\text { Technology tools } \\
\text { (click all that apply) }\end{array}$ & $\begin{array}{l}\text { Describe the rational of using } \mathbf{t} \\
\text { (if you are not planning to us } \\
\text { resources) }\end{array}$ & $\begin{array}{l}\text { hnology in meeting curriculum goals } \\
\text { technology, please justify your choice of }\end{array}$ \\
\hline
\end{tabular}

\begin{tabular}{|c|c|c|}
\hline $\begin{array}{l}\text { Brief description of the teaching/learning procedures } \\
\text { (How you are going to teach the content with technology) }\end{array}$ & $\begin{array}{c}\text { Reason for using } \\
\text { technology } \\
\text { (click all that apply) }\end{array}$ & $\begin{array}{l}\text { Describe the rational of using technology in meeting } \\
\text { science content or/and pedagogical objectives }\end{array}$ \\
\hline & $\begin{array}{c}\square \text { science content } \\
\square \text { pedagogical uses } \\
\square \text { Other }\end{array}$ & \\
\hline & $\begin{array}{c}\square \text { science content } \\
\square \text { pedagogical uses } \\
\square \text { Other }\end{array}$ & \\
\hline & $\begin{array}{c}\square \text { science content } \\
\square \text { pedagogical uses } \\
\square \text { Other }\end{array}$ & \\
\hline \multicolumn{3}{|c|}{ Explain what possible or likely failure points for the technology and suggest an alternate plan in case of a breakdown } \\
\hline
\end{tabular}




\section{Appendix G}

\section{Pathfinder Network Scaling - TPASK Concepts}

\section{What is Pathfinder Network Scaling?}

Pathfinder Network Scaling is an assessment tool, and it is commonly used to map learner's structural knowledge. Structural knowledge refers to the way learners conceptualize or understand the interrelationships between concepts of a particular domain of knowledge.

\section{Why am I using it?}

You will use this Rating Sheet to rate the relatedness of pairs of concepts as pertaining to inquiry learning, science content, and technology; as well as to indicate the rational of your rating.

\section{How does it work?}

Each pair of concepts will be rated on a numeric scale from completely unrelated (a rating of 1) to highly related (a rate of 5). Pathfinder Network Scaling will then transform the relatedness data into network representations via Knowledge Network Organizing Tool (KNOT) software program. In the network representation, each concept is represented by a node, and each relationship between two concepts is represented by a link between nodes. The highly related concepts are separated by more links, and the less related concepts are separated by fewer links or may be no links.

\section{What should I do?}

1) Judge the relatedness of each pair of the concepts shown in the rating sheet (select a rating from 1 to 5).

2) Write a short sentence to justify the Related and Highly Related ratings (i.e., ratings 4 and 5).

3) You have 30 minutes to complete the rating.

What are the concepts that I am going to rate?

\section{Knowledge related to Grade 8 Science}

1) Electric current: The flow of electrons in a conductor.

2) Electric circuit: A switch, battery, and device (load) are connected by connecting wires in a closed loop called electric circuit.

3) Measurement of voltage: Determines the amount of electric energy released per unit charge.

\section{Knowledge related to technology}

4) Multimedia projector: A device used to display a computer screen on a larger screen.

5) PhET Circuit Construction Kit simulation: A software program that simulates the construction of electric circuits by means of visual representation.

6) Evaluation of PhET Circuit Construction Kit simulation: The method used to assess the effectiveness of the PhET simulation in representing the construction of electric circuits.

\section{Knowledge related to classroom pedagogy}

7) Curriculum expectations related to Electricity: Specific expectations that learners are expected to achieve by the end of the unit on electricity.

8) Student's summative assessment: The method used by the teacher to assess students' learning at the end of the course or term.

9) Testing hypotheses: The process by which data are gathered and analyzed in order to test a previously postulated hypothesis.

\section{REFERENCES}

[1] International Society of Technology in Education. National Educational Technology Standards for Teachers, ISTE, USA, 2008.

[2] National Research Council. Educating teachers of science, mathematics, and technology: New practices for the new millennium, National Academy Press, USA, 2001.

[3] I. Lubin, X. Ge. Investigating the influences of a LEAPS model on preservice teachers' problem solving, metacognition, and motivation in an educational technology course, Education Technology research Development, Vol.60, 239-270, 2012.

[4] R. Phelps, A. Ellis. Overcoming computer anxiety through reflection on attribution, Winds of Change in the Sea of Learning: charting the course of digital education: Australasian Society for Computers in Learning in Tertiary Education (ASCILITE), Auckland, 8-11 December. Available online at: www.unitec.ac.nz/ascilite/ (accessed 8 May 2013). (2002c).

[5] H. So, B. Kim. Learning about problem based learning: Student teachers integrating technology, pedagogy and content knowledge, Australian Journal of educational technology, Vol. 25, No.1, 101-116, 2009.

[6] P. Mishra, M. Koehler. Technological Pedagogical Content Knowledge: A framework for teacher knowledge, Teachers College Record, Vol.108, No.6, 1017-1054, 2006.

[7] W. R. McCrory. Science, technology, and teaching the topic-specific challenges of TPCK in science. In AACTE Committee on Innovation and Technology (Eds.), Handbook of technological pedagogical content knowledge (TPCK) for educators, 193 - 206, Routledge, USA, 2008.

[8] L. Markauskaite. Exploring the structure of trainee teachers' ICT literacy: the main components of and relationships between, general cognitive and technical capabilities, Education Technology Research Development, Vol.55, 547-572, 2007.

[9] J. S. Brown, A. Collins, P. Duguid,. Situated cognition and the culture of learning. Educational Researcher, Vol.18, No.1, 32-42, 1989.

[10] PhET Interactive Simulations, University of Colorado Boulder, available online from http://phet.colorado.edu/index.php 
[11] M. Windschitl, J. Thompson, M. Braaten. How Novice Science Teachers Appropriate Epistemic Discourses Around Model-Based Inquiry for Use in Classrooms, Cognition and Instruction, Vol.26, 310-378, 2008.

[12] M. L. Niess. Preparing teachers to teach science and mathematics with technology: Developing a technological Pedagogical Content Knowledge, Teaching \& Teacher Education, Vol.21, No.5, 509-523, 2005.

[13] J. Azzarello. Use of the pathfinder scaling algorithm to measure students' structural knowledge of community health nursing, Journal of Nursing Education, Vol.46, No.7, 313-318, 2007.

[14] K. E. DicCerbo. Knowledge structures of entering computer networking students and their instructors, Journal of Information Technology Education, Vol.6, 263-277, 2007.

[15] D. L. Trumpower, T. E. Goldsmith. Structural enhancement of learning. Contemporary Educational Psychology, Vol.29, No.4, 426-446, 2004

[16] J. B. Harris, M. N. Grandgenett, M. Hofer. Testing a TPACK-Based Technology Integration Assessment Rubric. In Maddux, C. D. (Ed.), Research Highlights in Technology and Teacher Education (pp. 323-334), SITE, USA, 2010.

[17] L. D. Housner, R. L. Gomez, D. C. Griffey. A pathfinder analysis of pedagogical knowledge structures: A follow-up investigation, Research Quarterly for Exercise and Sport, Vol.64, No.3, 291-299, 1993.

[18] D. L. Trumpower, M. Filiz, G. Sarwar. Assessment for Learning Using Digital Knowledge Maps. In Digital Knowledge Maps in Education, 221 - 237, Springer, USA, 2014.

[19] A. Jimoyiannis. Designing and implementing an integrated technological pedagogical science knowledge framework for science teacher's professional development, Computers \& Education, Vol.55, No.3, 1259-1269, 2010.

[20] H. Tokmak, H. Surmeli, S. Ozgelen. Preservice science teachers' perceptions of their TPACK development after creating digital stories, International Journal of Environmental \& Science Education, Vol.9, 247-264, 2014.

[21] M. Kelly. Bridging digital and cultural divides TPACK for equity of access to technology. In AACTE Committee on Innovation and Technology (Eds.), Handbook of technological pedagogical content knowledge (TPCK) for educators (pp. 31-58), Routledge, USA, 2008.

[22] R. McCrory-Wallace. A framework for understanding teaching with the Internet, American Educational Research Journal, Vol.41, No.2, 447-488, 2004.

[23] P. A. Kirschner, J. Sweller, R. E. Clark. Why minimal guidance during instruction does not work: An analysis of the failure of constructivist, discovery, problem-based, experiential, and inquiry based teaching, Educational Psychologist, Vol.41, 75-86, 2006.

[24] R. S. Earle. The integration of instructional technology into public education: Promises and Challenges, ET Magazine, Vol.42, No.1, 5-13, 2002.

[25] M. L. Niess. Preparing teachers to teach science and mathematics with technology: Developing a technological Pedagogical Content Knowledge, Teaching \& Teacher Education, Vol.21, No.5, 509-523, 2005.

[26] Radford, D., Ramsey, L. Experiencing scientific inquiry and pedagogy: A model for in-service training for science education reform, Paper presented at the Annual Meeting of the National Association for Research in Science Teaching, $1-13,1996$.

[27] Periago, M., Bohigas, X. A study of second-year engineering students' alternative conception about electric potential, current intensity and Ohm's las. European Journal of Engineering Education, Vol.30, No.1, 71-80, 2005.

[28] Piaget, J. Piaget's theory, in P. H. Mussen (Ed.), Carmichael's manual of child psycology (pp. 703-732), Wiley, New York, 1970.

[29] Vygotsky, L. Mind in society: The development of higher psychological processes, Harvard University Press, Cambridge - MA, 1978.

[30] White, R., Gunstone, R. Probing understanding, Routledge, New York, 1992.

[31] Miles, M. B., Huberman, A. M. Qualitative data analysis: An expanded sourcebook ( $2^{\text {nd }}$ Edition $)$ SAGE Publications, London, 1994. 